\title{
ENABLING SMART URBAN REDEVELOPMENT IN INDIA THROUGH FLOOR AREA RATIO INCENTIVES
}

Apoorva Shenvi and Ron H. Slangen

NO. 58

July 2018

ADB SOUTH ASIA
WORKING PAPER SERIES 
ADB South Asia Working Paper Series

\section{Enabling Smart Urban Redevelopment in India through Floor Area Ratio Incentives}

Apoorva Shenvi and Ron H. Slangen

No. 58 | July 2018
Apoorva Shenvi was a former ADB intern and has a masters degree in urban planning from Harvard University.

Ron $\mathrm{H}$. Slangen is a senior urban development specialist at the Asian Development Bank. 
(C) 2018 Asian Development Bank

6 ADB Avenue, Mandaluyong City, 1550 Metro Manila, Philippines

Tel +632632 4444; Fax +6326362444

www.adb.org

Some rights reserved. Published in 2018.

ISSN 2313-5867 (print), 2313-5875 (electronic)

Publication Stock No. WPS189452-2

DOI: http://dx.doi.org/10.22617/WPS189452-2

The views expressed in this publication are those of the authors and do not necessarily reflect the views and policies of the Asian Development Bank (ADB) or its Board of Governors or the governments they represent, including the Government of India.

ADB and the Government of India do not guarantee the accuracy of the data included in this publication and accepts no responsibility for any consequence of their use. The mention of specific companies or products of manufacturers does not imply that they are endorsed or recommended by ADB or the Government of India in preference to others of a similar nature that are not mentioned. By making any designation of or reference to a particular territory or geographic area, or by using the term "country" in this document, ADB and the Government of India do not intend to make any judgments as to the legal or other status of any territory or area.

This work is available under the Creative Commons Attribution 3.0 IGO license (CC BY 3.0 IGO) https://creativecommons.org/licenses/by/3.0/igo/. By using the content of this publication, you agree to be bound by the terms of this license. For attribution, translations, adaptations, and permissions, please read the provisions and terms of use at https://www.adb.org/terms-use\#openaccess.

This CC license does not apply to non-ADB copyright materials in this publication. If the material is attributed to another source, please contact the copyright owner or publisher of that source for permission to reproduce it. ADB cannot be held liable for any claims that arise as a result of your use of the material.

Please contact pubsmarketing@adb.org if you have questions or comments with respect to content, or if you wish to obtain copyright permission for your intended use that does not fall within these terms, or for permission to use the ADB logo.

The ADB South Asia Working Paper Series is a forum for ongoing and recently completed research and policy studies undertaken in ADB or on its behalf. It is meant to enhance greater understanding of current important economic and development issues in South Asia, promote policy dialogue among stakeholders, and facilitate reforms and development management.

The ADB South Asia Working Paper Series is a quick-disseminating, informal publication whose titles could subsequently be revised for publication as articles in professional journals or chapters in books. The series is maintained by the South Asia Department. The series will be made available on the ADB website and on hard copy.

Notes:

In this publication, “\$” refers to United States dollars.

ADB recognizes "Hong Kong" as Hong Kong, China.

Corrigenda to ADB publications may be found at http://www.adb.org/publications/corrigenda. 


\section{CONTENTS}

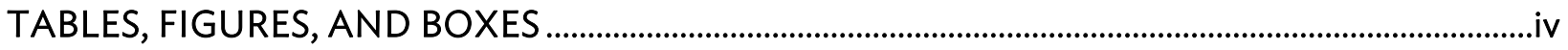

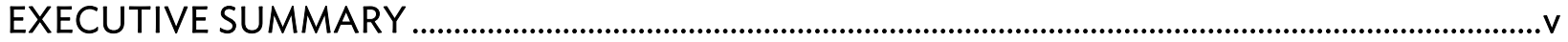

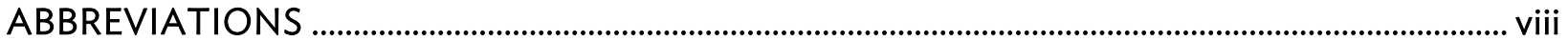

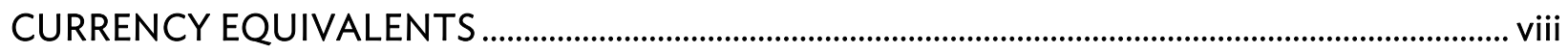

I. INTRODUCTION: THE HORIZONTAL EXPANSION OF CITIES IN INDIA .........................

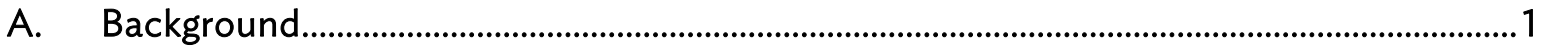

B. Growing Need of Indian Cities to Mobilize Own Finance ........................................................... 2

C. Critical Role of Floor Area Ratio Incentives in Urban Redevelopment ............................... 3

II. POLICY AND REGULATORY CONTEXT OF URBANIZATION IN INDIA .......................... 10

A. The Urban Land (Ceiling and Regulation) Act, 1976 ..................................................... 10

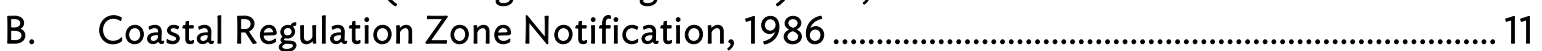

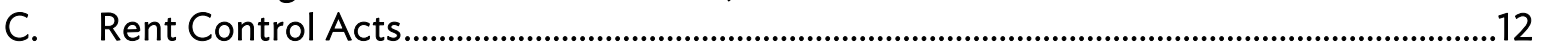

D. Current Zoning Practices in Major Metropolitan Cities......................................................13

E. Socioeconomic Impacts of Restricting Density .........................................................14

F. The Jawaharlal Nehru National Urban Renewal Mission ......................................................15

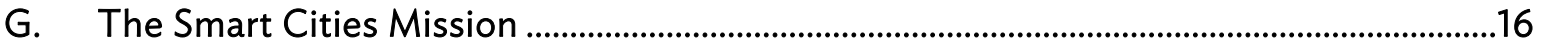

III. CASE STUDIES: AREA-BASED REDEVELOPMENT APPROACHES IN INDIA ......................17

A. Cluster Redevelopment in Mumbai ................................................................................................. 17

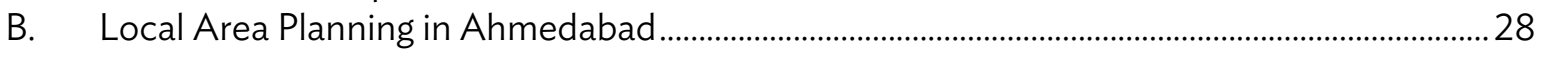

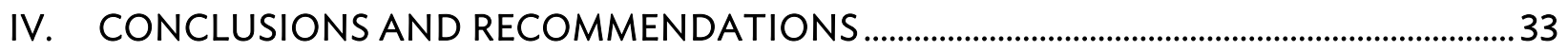

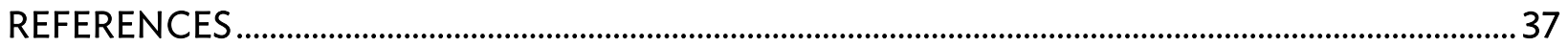




\section{TABLES, FIGURES, AND BOXES}

\section{TABLES}

$1 \quad$ City Center Floor Area Ratio Values in Different Cities ........................................................................14

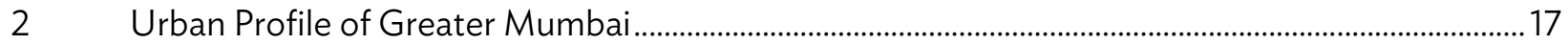

3 Classification of Cess Properties in Mumbai ..................................................................................................18

$4 \quad$ Floor Area Ratio for Redevelopment of Two or More Plots under DCR 33(7) ..............................19

$5 \quad$ Incentive Floor Area Ratio under DCR 33(9) ...........................................................................................2 20

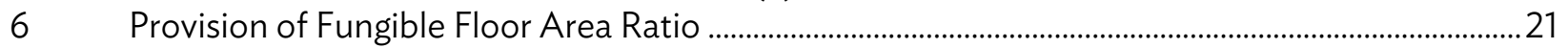

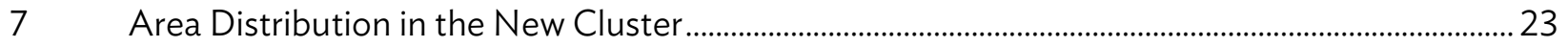

8 Development Charges Paid to Municipal Corporation of Greater Mumbai for the Bhendi Bazaar Redevelopment............................................................................................................ 23

$9 \quad$ Property Tax Schedule for Rehabilitated Occupants............................................................................24

10 Municipal Corporation of Greater Mumbai Income in 2013-2014 _..................................................24

11 Analysis of Cluster Redevelopment in Mumbai ....................................................................................26

$12 \quad$ Urban Profile of Ahmedabad Urban Area .................................................................................................2 29

13 Permissible Floor Area Ratio in Ahmedabad .................................................................................................2 29

$14 \quad$ Existing and Proposed Scenario for the Ahmedabad City Center ........................................................30

$15 \quad$ Expected Revenue from Premium Floor Area Ratio ............................................................................. 31

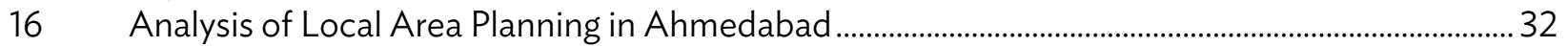

\section{FIGURES}

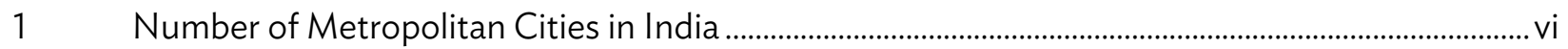

$2 \quad$ Population in Metropolitan Cities............................................................................................................

3 Capital Expenditure Estimates by Sector 2012-2031 ..........................................................................2

$4 \quad$ Financing Urban Infrastructure 2031-2032 ......................................................................................

5 Municipal Finances: Declining Share of Own Revenue 2002-2003 to 2007-2008 ......................3

$6 \quad$ Floor Area Ratio Values in Cities in India .........................................................................................

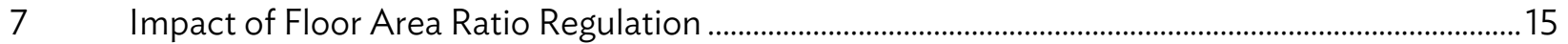

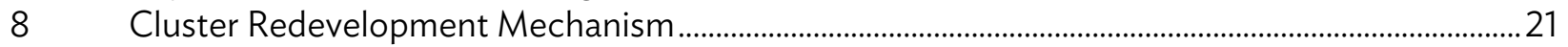

9 Municipal Corporation of Greater Mumbai Revenue Distribution, 2013-2014 ............................. 25

10 Development Charges from Bhendi Bazaar................................................................................................. 25

11 Impact of Cluster Redevelopment Policy on Affordability.....................................................................2 26

12 Mechanism for Rejuvenating the Ahmedabad City Center ..................................................................30

13 Recommendations for Administering Redevelopment Using Floor Area Ratio Incentives........ 34

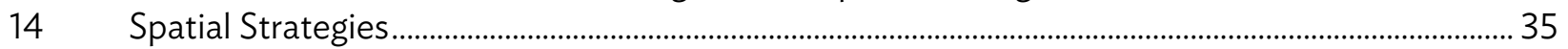

15 Fiscal Incentives and Strategies to Promote Inclusive Redevelopment .............................................36

\section{BOXES}

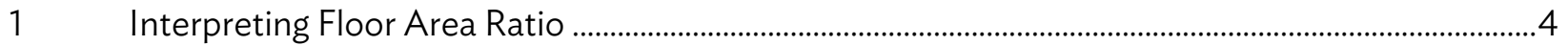

$2 \quad$ Incentive Zoning in New York City ........................................................................................................

3 Urban Operations and Use of Certificates of Potential Additional Construction

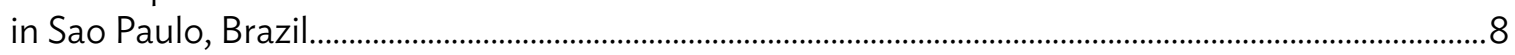

$4 \quad$ Vanderbilt Corridor Rezoning: Linking New Commercial Development to Transit and Public Realm Improvements ......................................................................................... 27

5 Use of Certificates of Potential Additional Construction Bonds to Rejuvenate Porto Maravilha in Rio De Janeiro, Brazil 


\section{EXECUTIVE SUMMARY}

At a time when cities worldwide are actively engaged in promoting sustainable development and mitigating climate change through transit-oriented development (TOD) strategies, India's transition from a predominantly agrarian economy to a rapidly urbanizing country provides a unique opportunity for its cities to leverage available resources and plan for a sustainable and low-carbon future. Cities such as New Delhi and Ahmedabad recently implemented policies that integrate urban planning strategies such as TOD, taking advantage of investments in transit infrastructure to achieve a dense and compact urban form along transport corridors, promote walkable, mixed-use neighborhoods, and reduce use of motorized vehicles. Such policies - coupled with land-based financing mechanisms-are a promising avenue for mobilizing finance for urban services, and unlocking the development potential of deteriorating urban neighborhoods. India's Smart Cities Mission is a national-level urban initiative that is raising awareness of such approaches, and encouraging urban local bodies (ULBs) to promote areabased development and leverage floor area ratio (FAR) incentives to attract private sector investment.

Floor area ratio-defined as the ratio of total floor area versus the size of the plot of land on which a building is constructed-is relatively low in Indian metropolises compared to other major cities globally. Even though many Indian cities are among the most densely populated in the world, they tend to have low FARs. The result is extreme scarcity of urban space in city centers, low per-capita land consumption, and exceptionally high property values and rents, leading to unplanned expansion of city margins. These margins are generally characterized by a proliferation of slums, a deficit of urban infrastructure and services, and high environmental pollution. If Indian cities are to revitalize their centers through innovative FAR policy reform to encourage high-density, mixed-use development, and promote a compact urban form as part of an overall strategy of integrated urban and regional growth, they can leverage the advantages of agglomeration, and improve livability.

In the last 2 decades, India's urban population has increased exponentially, with 420 million Indians$33 \%$ of the population-living in cities in 2015. Experts estimate that urbanization will peak in 2050, with more than half of India's population living in cities. ${ }^{*}$ The growth rate of small- and medium-sized towns in India is much higher than its metropolitan cities (cities with a population above one million), which in recent years, have seen their population decline but grow on their peripheries. This pattern can be broadly attributed to low FARs and inadequate public transit services-limiting the development potential of city centers - coupled with a shift of manufacturing bases to urban peripheries. That said, according to the 2011 census, nearly half of India's urban population (42.3\%) still resides in one of its 50 metropolitan cities (see Figures 1 and 2). Thus, these cities will play an important role in maintaining existing populations, attracting and absorbing new populations, while curbing unsustainable growth patterns at the peripheries.

FAR incentives or "density bonuses," have been used in several cities around the world to encourage certain types of development, and also to offset public infrastructure costs using private sector investment. Through its incentive zoning approach, New York City permitted private developers to utilize higher FARs than usual in exchange for carrying out improvements to public areas around transit stations, building plazas and parks, and undertaking sidewalk improvements, etc. In 2001, Brazil passed a legislation that separates land ownership rights from the right to build, enabling cities to specify the floor-area potential of urban land parcels, and increase and auction additional potential in designated areas through "urban operations." Cities such as Sao Paulo and Rio de Janeiro used revenue obtained from auctioning building rights to augment urban infrastructure such as roads, water supply and

Tewari, M., Godfrey. N., et al. 
sewerage, and public spaces. In both the United States and Brazil, these approaches have been instrumental in the creation of high-density, mixed-use neighborhoods that are serviced by public transit. Thus, undertaking urban redevelopment of deteriorating urban neighborhoods and providing an impetus to TOD through FAR incentives is a promising approach.

Figure 1: Number of Metropolitan Cities in India

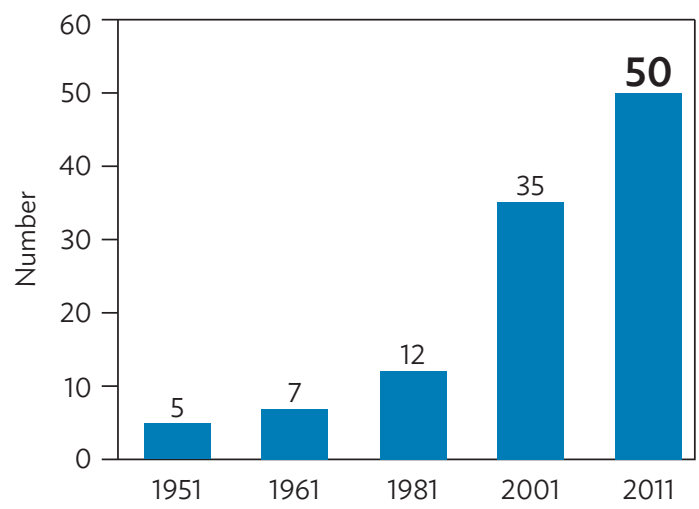

Note: Data relates to urban agglomerations with populations above 1 million.

Source: Government of India (2011).
Figure 2: Population in Metropolitan Cities

(\%)

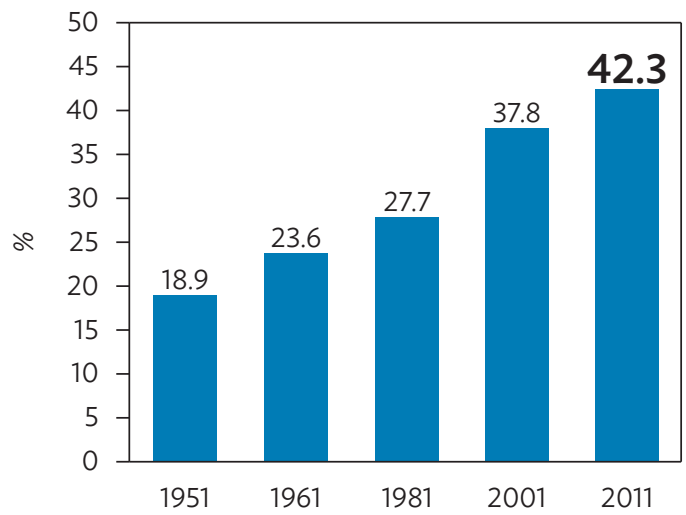

Note: Data relates to urban agglomerations with populations above 1 million.

Source: Government of India (2011).

This working paper assesses the potential of incentive FAR approaches in two Indian cities, Mumbai and Ahmedabad, for leveraging the economic value of urban land. A thorough analysis of Mumbai's cluster redevelopment approach revealed this mechanism has substantial potential for augmenting municipal revenue and contributing to public infrastructure improvements. However, its success is highly dependent on the local land and real estate markets, and it may not result in sustainable and inclusive development in the long term. Additionally, it also has significant spatial impacts that need to be considered when adapting this approach for other contexts. On the other hand, Ahmedabad's proposal for rejuvenating its central business district is still in its early stages, and requires careful assessment of land markets in the city, as well as infrastructure and service requirements generated by the increased population density. The implementing agencies need to formulate a mechanism that enables them to link revenue obtained from additional FAR to infrastructure improvements in the area from which it originates.

Incorporating some key lessons from international approaches with prevailing incentive-based FAR redevelopment approaches will be a tangible way forward for Indian cities. Cities can formulate legislation that facilitates integration of urban redevelopment initiatives with their overall development plans and long-term vision for growth, rather than treating them as stand-alone projects. While rezoning existing urban neighborhoods for different uses and higher densities, cities should undertake comprehensive impact analysis on infrastructure and transportation networks, natural systems and water bodies, and the overall urban form. They should mandate a public consultation and review process, prior to development approvals. Cities can also explore an approach similar to Brazil's efforts to link FAR increases and related revenues to infrastructure improvements in the areas where the FAR 
incentives apply. Indian cities can use this mechanism to promote development of pedestrian-friendly, compact, mixed-use neighborhoods that are accessible by multimodal transit systems. This will significantly reduce the carbon footprint of new developments and mitigate long-term climate change.

This research study was qualitative and undertaken through literature reviews, case studies, key stakeholder and expert interviews, and secondary data collection. Quantitative data sources include government websites, city records, and reviewed literature.

The South Asia Urban and Water Division (SAUW) of the Asian Development Bank (ADB) led this research study. Sekhar Bonu, director, SAUW; Ron H. Slangen, senior urban development specialist, SAUW; and Ashok Srivastava, senior project officer (Urban), ADB India Resident Mission supervised the study. Apoorva Shenvi, graduate student, Harvard University Graduate School of Design was the lead researcher. Stefan Rau, urban development specialist, ADB East Asia Department and Jagan Shah, director, National Institute of Urban Affairs, New Delhi peer reviewed the paper. The team wishes to acknowledge the support of the Government of India's Ministry of Urban Development, and the National Institute of Urban Affairs. The team thanks Vidyadhar Phatak (dean of Planning, CEPT University and former chief planner, Mumbai Metropolitan Region Development Authority); Ashutosh Limaye (head of Research, JLL India); Saswat Bandyopadhyay (professor of infrastructure planning, CEPT University); PK Ghosh (former municipal commissioner, Ahmedabad Municipal Corporation); various local and state government officials; private developers; and project consultants who contributed time and inputs during the study. 


\section{ABBREVIATIONS}

$\begin{array}{lll}\text { ADB } & - & \text { Asian Development Bank } \\ \text { AMC } & - & \text { Ahmedabad Municipal Corporation } \\ \text { AMRUT } & - & \text { Atal Mission for Rejuvenation and Urban Transformation } \\ \text { AUDA } & - & \text { Ahmedabad Urban Development Authority } \\ \text { BRTS } & - & \text { bus rapid transit system } \\ \text { CBD } & - & \text { central business district } \\ \text { CRZ } & - & \text { coastal regulation zone } \\ \text { DCR } & - & \text { development control regulations } \\ \text { FAR } & - & \text { floor area ratio } \\ \text { FSI } & - & \text { floor space index } \\ \text { GIS } & - & \text { geographic information system } \\ \text { HPEC } & - & \text { High Powered Expert Committee } \\ \text { JNNURM } & - & \text { Jawaharlal Nehru National Urban Renewal Mission } \\ \text { MBRRB } & - & \text { Mumbai Building Repairs and Reconstruction Board } \\ \text { MCGM } & - & \text { Municipal Corporation of Greater Mumbai } \\ \text { MHADA } & - & \text { Maharashtra Housing and Area Development Authority } \\ \text { MMRDA } & - & \text { Mumbai Metropolitan Region Development Authority } \\ \text { MoEF } & - & \text { Ministry of Environment, Forest and Climate Change } \\ \text { MoUD } & - & \text { Ministry of Urban Development, Government of India } \\ \text { NOC } & - & \text { no objection certificate } \\ \text { PWC } & - & \text { PriceWaterhouseCoopers } \\ \text { SBUT } & - & \text { Saifee Burhani Upliftment Trust } \\ \text { TDR } & - & \text { transfer of development rights } \\ \text { TOD } & - & \text { transit-oriented development } \\ \text { ULB } & - & \text { urban local body } \\ \text { ULCRA } & - & \text { Urban Land (Ceiling and Regulation) Act, 1976 } \\ & & \end{array}$

\section{CURRENCY EQUIVALENTS}

(As of July 2015)

$\begin{array}{ll}\text { Currency Unit } & \text { Indian Rupee (₹) } \\ \$ 1 & ₹ 63.49 \\ € 1 & ₹ 69.13\end{array}$




\section{INTRODUCTION: THE HORIZONTAL EXPANSION OF CITIES IN INDIA}

\section{A. Background}

1. An exponentially expanding urban population has put tremendous strain on Indian cities, as the rate of people migrating to cities in pursuit of better economic opportunities increased significantly over the past 2 decades. As of 2011, India was 32\% urbanized; the United Nations predicts that this will increase to $50 \%$ by 2050 . Urban infrastructure development, including water supply and affordable housing, has not kept pace with urbanization trends, resulting in low service delivery levels and poor urban, public, and environmental health conditions. Promoting sustainable urban growth is key to resource efficiency and inclusive development of cities in India.

2. Urban development policies in India sought to limit densification of central areas of the city by imposing low floor area ratios (FARs). This resulted in the spatial expansion of many urban areas. In recent years, urban sprawl has become unmanageable, with governments struggling to provide urban services to the urban peripheries. Numerous state and city governments recognized the inefficiency of this mode of development and revised their development plans. In Ahmedabad, the Ahmedabad Urban Development Authority (AUDA) and the Ahmedabad Municipal Corporation (AMC) classified the city into zones based on predominant land usage and assigned FAR for each zone. Mumbai's contested 2014-2034 Development Plan also proposed zones with an FAR of up to 8 in some areas of the Island City.

3. Recent land use trends in cities in India. Cities like Ahmedabad and New Delhi are exploring the interface between transportation and land use planning through Transit-oriented development (TOD) strategies such as permitting higher FARs and building heights along major rapid transit corridors. Since most of these corridors pass through brownfield urban areas, TOD has been underutilized to date. Still in its nascent stages, the TOD policy in India has great scope for improvement, to achieve its objective of exploiting the potential of transit corridors to create a compact urban form and enhance pedestrian accessibility. The Delhi Development Authority (DDA) has recently developed extensive guidelines to implement TOD in New Delhi, which are expected to provide impetus to the redevelopment of old neighborhoods in the city.

4. Urban redevelopment in cities in India has mostly been limited to slum redevelopment or rehabilitation of deteriorating residential areas through FAR incentives. The Bhendi Bazaar Project in Mumbai is the only example of cluster redevelopment in the country. The clusters are however, not a part of the overall city development plan. The Smart Cities Mission is the first national-level urban program in the country, to propose an initiative to undertake retrofit and redevelopment of urban areas.

5. The most common form of mixed-use development in Indian cities is retail and office uses on the ground floor and residential uses on the upper floors. A vertical mix of residential and commercial uses or a mix of residential, and institutional, recreational, or industrial uses is uncommon.

6. Cities such as Hyderabad, Chennai, Mumbai, and New Delhi regulate urban form by permitting FARs based on plot sizes and imposing setback restrictions - or a combination of both. The regulations do not include urban design guidelines to promote uniformity in urban neighborhoods by imposing height limits, façade regulations, etc. As a result, new development has not contributed to improving the overall urban fabric. 


\section{B. Growing Need of Indian Cities to Mobilize Own Finance}

7. The High Powered Expert Committee (HPEC) appointed by the Ministry of Urban Development (MoUD) projected urban infrastructure investment requirements of $\$ 612$ billion at 2009-2010 prices for the 12th to 15th Five-Year Plans-from 2012-2013 to 2031-2032 (HPEC 2011). A significant portion (56\%) of this projected investment is required for constructing urban roads (Figure 3). If spatial expansion of cities is contained, some of the projected investment can be redirected to other sectors.

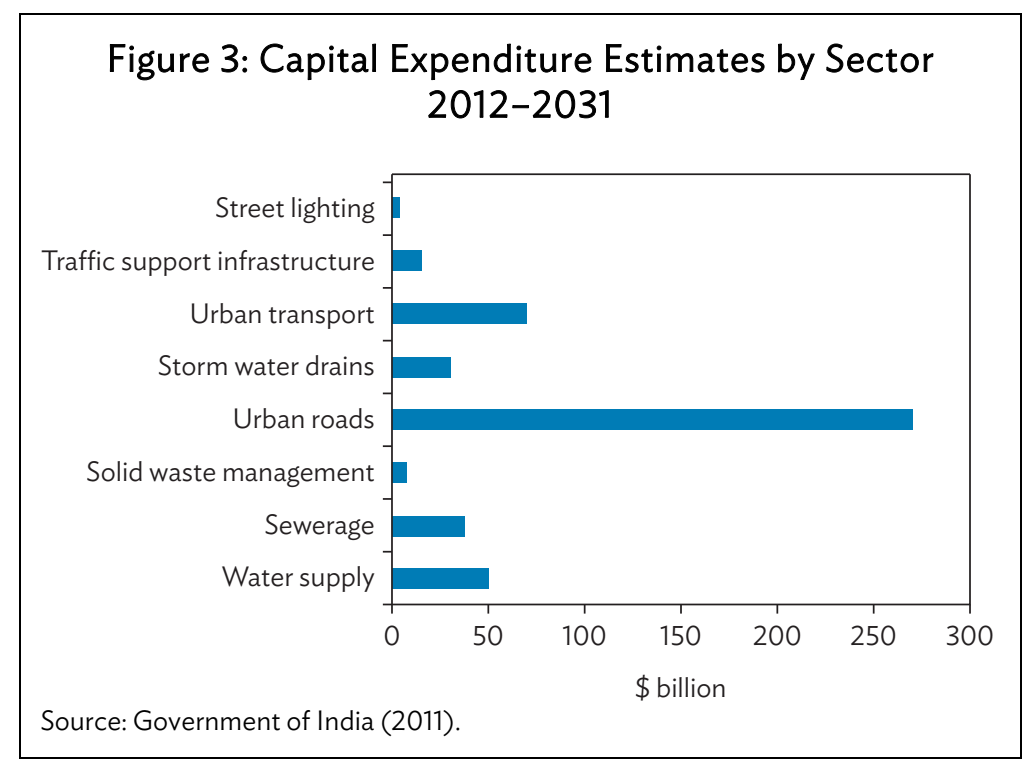

8. HPEC stated that urban local bodies (ULBs) need to raise $68 \%$ of these funds from their own revenues (Figure 4). However, municipal revenues declined over the past decade (Figure 5). Hence, HPEC identified numerous measures that would make it possible for ULBs to mobilize resources for financing urban infrastructure. These measures highlight the importance of tapping land-based financing sources, including conversion charges, betterment charges, impact fees, and development charges. HPEC strongly recommended pricing of FAR above a certain limit, within overall planning guidelines (HPEC 2011).

9. Success of land-monetization. The city of Mumbai has been very successful in exploiting demand for land in the city by separating the development potential of a plot from its ownership. The Municipal Corporation of Greater Mumbai (MCGM) earned significant revenue through its transfer of development rights (TDR) policy of selling development right certificates, and its more recent fungible FAR policy. This approach is quite similar to the certificates of potential additional construction bonds (CEPACs) auctions in Sao Paulo, Brazil. Sale of premium FARs was not met with much success in Ahmedabad, where a wideranging study of the market demand was not undertaken prior to assigning FAR premiums.

10. Development charges contribute 4\% to MCGM's annual revenue. As evidenced in the Mumbai case study (discussed in detail later), a single cluster redevelopment project can generate $5 \%$ of the development charges currently being earned by MCGM. Thus, replicating this development model in other areas of the city will make a sizable contribution to municipal revenue. 


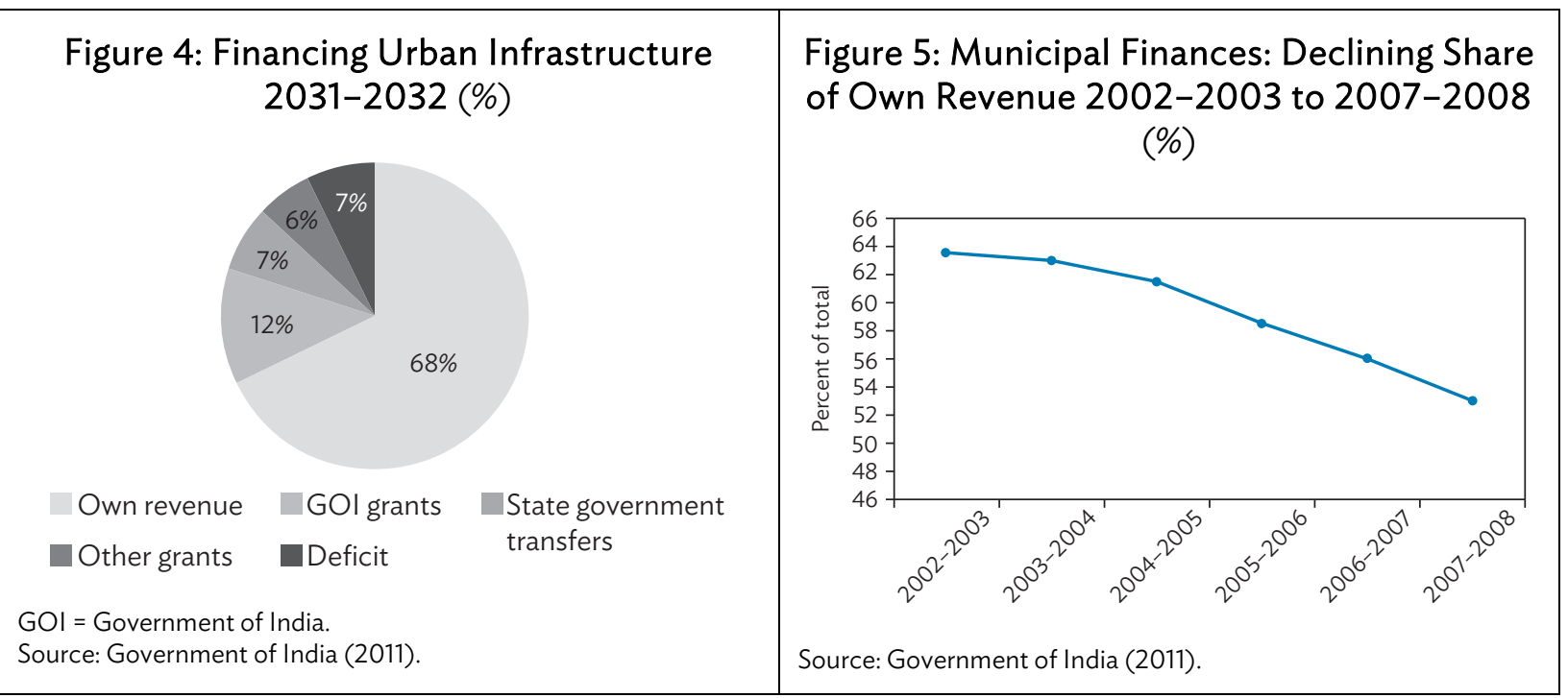

11. Even though property taxes are the second largest contributor to MCGM's revenue, the increase in income from property taxes is yet to be assessed. Data from individual redevelopment projects is difficult to assemble and cluster redevelopment projects are yet to be completed. However, the limited rebates given to the occupants of rehabilitated properties, coupled with the calculated tax on their capitalized value, will certainly cause an overall increase in property tax collection from redeveloped properties.

12. Cities such as Ahmedabad and Hyderabad have provisions for collecting betterment charges and city-level impact fees to ensure that developers pay for increases to their property values owing to the provision of urban services. This income is utilized to implement new infrastructure projects and improve existing amenities.

13. For FAR incentives to be successful, the land market needs to be very well developed. In India, land markets are very diverse. Although increased land prices is a common trend in all cities, irrespective of their size, the property market is currently experiencing a slump. Hence, a blanket approach to FAR incentives will yield varying results depending on the city and region.

14. Selling TDR and premium FAR is a complex mechanism that requires administrative capacity and an efficient ULB. Currently, only India's major metropolitan cities have the requisite implementation capacity. Improving the capacities of municipal officials in other ULBs is key to the success of this approach.

\section{Critical Role of Floor Area Ratio Incentives in Urban Redevelopment}

15. Floor area ratio (FAR) - defined as the ratio of total built-up area on a plot to the area of that plot-in cities in India is maintained at a low level due to the rationale that existing infrastructure in these cities cannot support additional development or increases in population (Box 1). Most cities in India have a blanket FAR (Figure 6) with slight variances across the city that limit the opportunity to leverage infrastructure nodes and networks for high-density development. Additionally, although the primary opposition to increasing FAR in India stems from urban infrastructure constraints, removing FAR restrictions is imperative to procure investments for upgrading urban infrastructure and services. 


\section{Box 1: Interpreting Floor Area Ratio}

It is important to note that the same floor area ratio (FAR) can lead to different building configurations and building heights on the same land parcel, depending on underlying zoning regulations. Cities define plot coverage ratios for buildings (minimum open space on the ground as a percentage of the total site area), outline guidelines for access roads and on-site roads, and specifiy setback requirements (distance between each edge of the plot and the building) on one or more sides to regulate built form, natural light and ventilation, and open space. Thus, an FAR of 2.5 can lead to mid-rise buildings with high plot coverage and fewer setbacks, or high-rise towers with lower plot coverage, and more setbacks.

Source: Authors.

16. Moreover, in India's otherwise liberalized economic policy environment, stringent regulations on urban development densities are pushing businesses and people out of urban cores (World Bank 2013). These constraints on land use restricted growth in central areas in cities, driving up property values and making housing expensive. Poor and middle-class households have been priced out from urban centers and commuting costs for workers have increased (World Bank 2013).

17. Recognizing the pressing need to rejuvenate cities in India in order to stimulate economic development, the Ministry of Urban Development (MoUD) launched the Smart Cities Mission in June 2015 , with an outlay of $\$ 7.5$ billion. The program will run for 5 years and cover 100 cities, with the primary objective of upgrading urban infrastructure in existing Indian cities, using smart technology, and governance strategies, promoting high-density, mixed use, area-based development that is inclusive and sustainable. The mission guidelines recommend the use of high FAR, with FAR bonuses to stimulate urban redevelopment in the cities. ${ }^{1}$

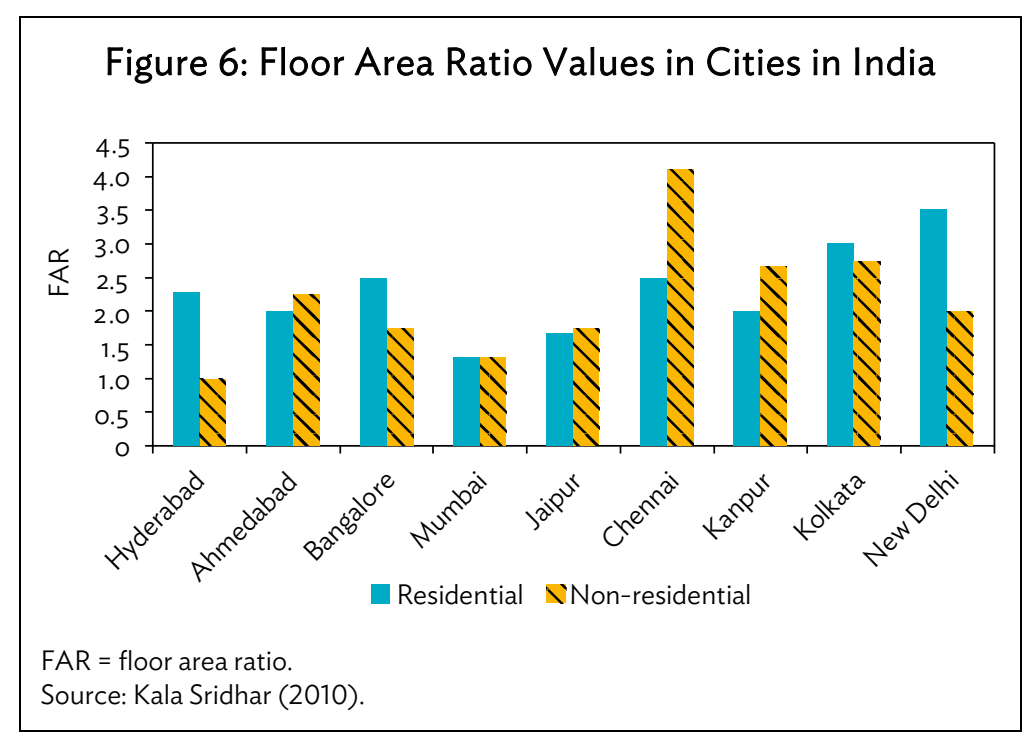

${ }^{1}$ Government of India, Ministry of Urban Development. (2015). 
18. Urban redevelopment using incentive FARs is a relatively recent planning practice in India - first implemented as policy in Mumbai in 1991. ULBs are utilizing it as a fiscal tool to monetize development by permitting high FARs in demarcated areas. Cities such as New York (Box 2) have effectively used FAR bonuses and exploited the development potential of land to increase revenue through property taxes and procure infrastructure investments. HPEC recommends using FAR incentives to augment municipal revenues and generate funds for urban infrastructure in India. Hence, there is a need to assess this approach to develop innovative practices and strategies that can be incorporated into the urban redevelopment framework of cities.

19. This paper reviews FAR-based urban redevelopment as envisioned under the Smart Cities Mission to gain a better understanding of its potential and opportunities for improvement, with the following objectives:

(i) Assess potential of incentive FAR approaches for leveraging the economic value of urban land.

(ii) Determine the impacts of FAR incentives on municipal revenue, urban infrastructure, spatial growth and affordability.

(iii) Recommend good practices for making urban redevelopment schemes more effective and inclusive.

20. Need for integrated spatial and infrastructure planning. Globally, cities have leveraged public investments in transit corridors, transportation hubs, etc. to procure private investment in public services by permitting higher densities around such infrastructure. When new transit lines are planned, cities update their spatial plans to permit higher densities and a mix of land uses in the vicinity of these lines, to encourage transit-oriented development. Private developers can acquire higher FAR than currently permitted by paying a premium. This revenue is used by cities to recover a portion of their transit investment, while also augmenting public services in these areas to support increased demand. The advantage of this approach is twofold. Integrating spatial growth with infrastructure provision enables cities to develop sustainable, walkable neighborhoods, while at the same time improve public infrastructure through private sector investments.

21. ULBs in India have separate departments that deal with various infrastructure demands, such as roads, public transit, traffic management, water supply, etc. In some cities, parastatal agencies are responsible for certain infrastructure elements-examples include the Jal Board for water supply in Delhi, or Brihanmumbai Electric Supply \& Transport (BEST) Undertaking for power supply to Mumbai's Island City.

22. Budgetary provisions for infrastructure augmentation are made for every department, which separately assesses the need for capital investments in infrastructure under its management. Numerous citywide projects by each of these departments are ongoing at any given time.

23. The link between densification of transit corridors or urban clusters and the need to subsequently upgrade urban services in those areas has been insufficiently assessed. The preparatory studies done by MCGM prior to preparing the Development Plan 2034 for Mumbai is probably one of the most extensive studies conducted to analyze the impact of the proposed development plan on infrastructure, transport, urban services, and public health. 
24. A comprehensive analysis of the mechanisms of utilizing revenue generated by new built-up areas created by higher FARs to finance infrastructure requirements generated by this development has not been undertaken in India.

25. Levying user charges on urban dwellers and determining the magnitude of such charges is highly politicized. Successive governments have been reluctant to raise such charges. The Smart Cities Mission specifically emphasizes the need to collect user charges, and some cities have already started charging consumers for metered use of urban services. MCGM installed water meters and collects water taxes based on the readings. It has a similar provision for collecting sewerage tax.

26. Mumbai's cluster redevelopment policy requires complete overhauls of water and sewerage pipes, and power lines. Various MCGM departments and parastatal agencies assess individual building proposals for compliance with urban service standards prior to granting of a no objection certificate (NOC). However, the effect of urban redevelopment on overall service-delivery capacity remains unclear due to insufficient assessment of redevelopment at the city-level. New York City's incentive zoning approach enables property developers to acquire higher FARs than permitted by existing zoning in specific districts with high development potential by undertaking public-realm improvement projects. While rezoning these districts to assign a higher development potential, the city undertook an extensive assessment of the increased density and built-up area on the city's urban services and environment. Additionally, each project developed using this approach has to submit a comprehensive impact assessment, outlining the effect of the development on the traffic, urban services, and environment in the neighborhood and the city. The project also has to undergo an extensive review process, which ensures that the increased development potential of the site does not have adverse impacts on the overall urban environment. Since 2001, cities in Brazil have been using an "urban operations" mechanism to procure private investment in the overhaul of urban infrastructure, by designating urban operation areas, increasing their development potential, and selling development rights to private entities. Cities have carefully assessed the infrastructure requirements from increased development potential in such areas, and structured urban operations accordingly.

27. Land assembly and contested land titles have been one of the primary challenges in undertaking urban redevelopment in India. As a part of the Jawaharlal Nehru National Urban Renewal Mission (JNNURM) reforms, several Indian cities have now computerized property records and made property cards available to the public. This has significantly helped in clarifying property boundaries and ownership.

28. Leveraging technology and e-Governance. MoUD launched the National Urban Information System (NUIS) scheme in March 2006 to create geographic information system (GIS) databases for 152 towns and cities in India, using satellite images and aerial photography. Data generation for all 152 towns has been completed. Establishing a database of urban attributes, the National Urban Data Bank and Indicators (NUBDI), is also a component of this scheme. This data has been uploaded to the Bhuvan Portal. Under the NUIS scheme, capacity building in the use of GIS tools for spatial-data analysis was also undertaken for town planning personnel in state agencies and ULBs. Creating comprehensive GISbased spatial datasets with layers such as property, buildings, roads, urban service lines, and demographics is a prerequisite for cities to compete for funding under the Smart Cities Mission. This will expedite the master planning process and help ULBs plan and implement numerous urban improvement schemes. 
29. Getting approvals for master plans and buildings and acquiring NOCs from various departments within ULBs and parastatal agencies take time. Interpreting the development control regulations (DCRs) is complex, and revising proposals when objections are raised is laborious. Such delays can escalate project costs and discourage the private sector from investing in large-scale redevelopment projects. To make this process more time efficient, the Ministry of Municipalities Affairs and Urban Planning (MMAUP) of Bahrain initiated the One Stop Shop (OSS) project to get all urban development entities under a single agency. MMAUP set up an Information Systems Directorate (ISD) to coordinate, maintain, and analyze data between different municipalities in Bahrain. ISD used these datasets to create a web-based application to collect building permit requests and a desktop module for the municipal staff to track and manage building permits. During the application process, the applicant can choose a specific parcel from the map. The system defines the zoning regulation, which enables the applicant to design buildings accordingly and the officials to approve proposals based on underlying regulations (Kumar et al.). MCGM recently launched an online application for submitting building proposals. The status of each proposal and the documents submitted along with it can be viewed online by citizens. This single-window system, although relatively new, has been welcomed by developers and will help in making the approvals process transparent, and curb unethical practices. Thus, e-Governance can play a crucial role in streamlining development approval processed and significantly improve the ease of doing business in cities in India.

\section{Box 2: Incentive Zoning in New York City}

Zoning laws in New York City have continuously evolved to keep up with changing urban trends and technological advancements. The City Planning Commission has been instrumental in significantly improving the urban realm in the city by providing incentives to improve and maintain public spaces, and formulating strict urban design guidelines to regulate overall urban form. New York's Uniform Land Use Review Procedure is one of the most comprehensive and democratic procedures for approving zoning changes and new development in the world. Additionally, the zoning laws necessitate the undertaking of rigorous impact assessment studies on traffic, urban experience, urban services, public health, and the environment to name a few. Hence, New York's incentive zoning approach and approval mechanism can be analyzed for its applicability as a best practice.

New York City's Zoning Resolution of 1916 was the first comprehensive zoning ordinance in the United States. Many other cities adapted this ordinance, making New York City a pioneer in the field of zoning. Over the decades, the zoning regulation evolved in response to changing socioeconomic trends in the city. In the 1950s, a swelling population, emergence of new mass-transit routes and growth corridors, and the advent of new technologies created a need to reconsider zoning regulations in the city. After numerous assessments and comprehensive public engagement, a new zoning ordinance was created. New York City's 1961 Zoning Resolution coordinated land use and bulk regulations, incorporated parking requirements, and emphasized the creation of open spaces. It introduced the concept of incentive zoning, which encouraged private developers to undertake public-realm improvements in exchange for floor area ratio (FAR) bonuses. Incentive FARs could be obtained for the provision of public plazas (privately-owned public spaces), visual or performing arts spaces, subway improvements, theater preservation, fresh food stores - an incentive to promote the establishment and retention of neighborhood grocery stores-and affordable housing (the Inclusionary Housing Program). In 1969, the City Planning Commission (CPC) designated special zoning districts in the city to achieve specific planning and urban design objectives in demarcated areas with unique characteristics. These districts integrated zoning incentives that were tailored to CPC's development objectives. ${ }^{a}$ Incentive zoning systems are either discretionary, as-of-right, or a hybrid of the two. In the first case, the city retains the discretion to review proposals on a case-by-case basis. The 1961 Zoning Resolution adopted discretionary 
Box 2 continued

zoning, under which developers had little indication of how much density incentive they would obtain from the proposed public benefits before commencing negotiations with the city. This was a protracted and timeconsuming process, due to which the city later adopted an as-of-right zoning approach. It should be noted that proposals for incentive FAR under as-of-right zoning also need to undergo institutional reviews (Urban Land Institute 1989).

\section{Incentive Zoning Mechanism in New York City}

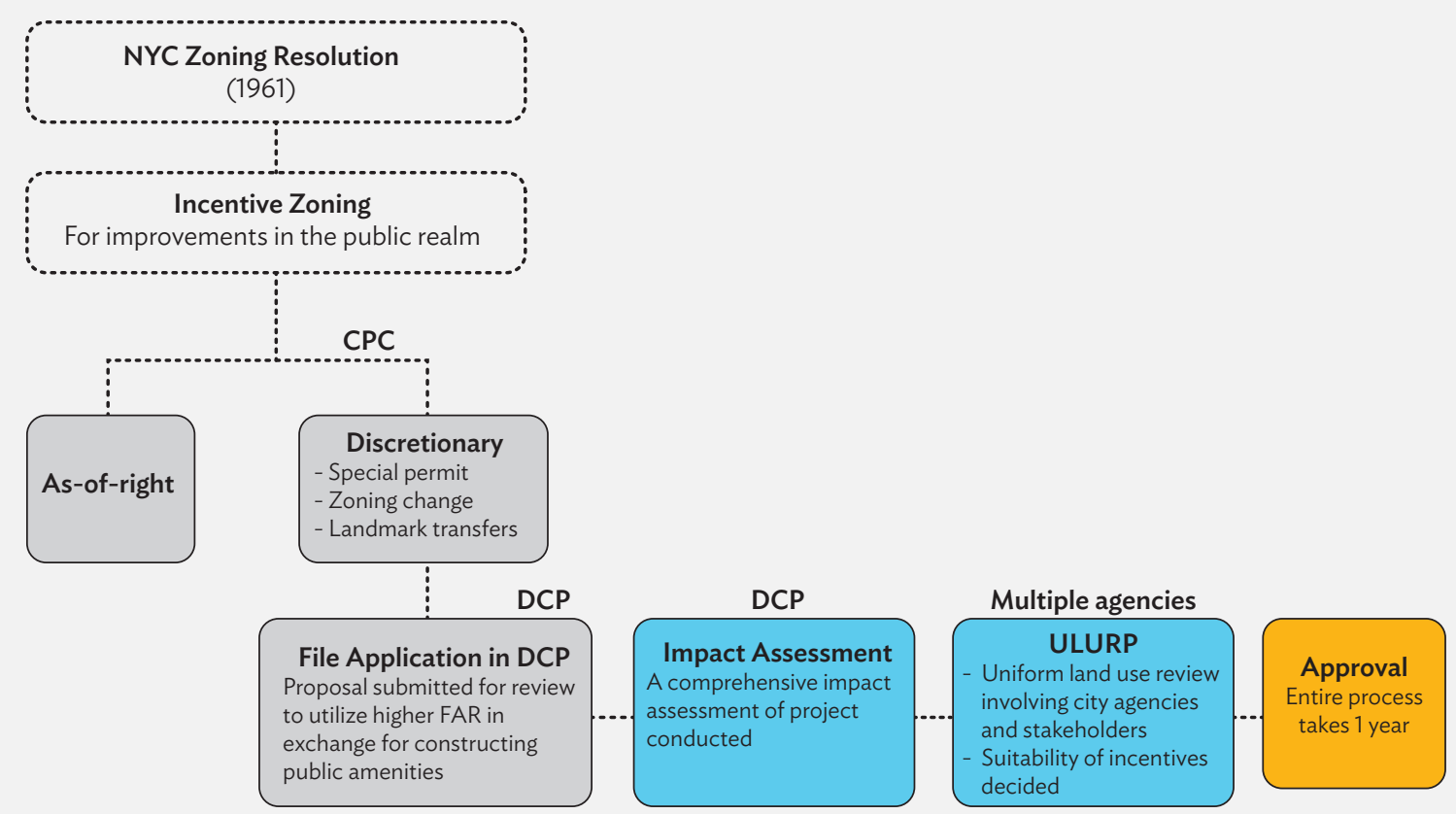

$\mathrm{CPC}=$ City Planning Commission, $\mathrm{DCP}=$ Department of City Planning, FAR $=$ floor area ratio, NYC $=$ New York City, ULURP $=$ Uniform Land Use Review Procedure.

Source: NYC Department of City Planning (illustration made by authors).

\section{Box 3: Urban Operations and Use of Certificates of Potential Additional Construction in Sao Paulo, Brazil}

Brazil and India have been on a similar growth trajectory for the last few decades. Hence, numerous parallels can be drawn between urbanization trends in cities in both countries. Sao Paulo is a megacity in Brazil, which faces urban pressures similar to many Indian metropolises. Sao Paulo's policy of issuing development potential certificates is identical to Mumbai's redevelopment policy. Through this policy, Sao Paulo has effectively developed innovative mechanisms for procuring private sector investment in urban infrastructure improvements.

In 1988, a new Constitution was approved in Brazil. Articles 182 and 183 concerned urban development, establishing the social function of land ownership and the separation of right of property from the right to construct. In 1990, the city of Sao Paulo adapted its Municipal Constitution from the Federal Constitution and regulated urban operations. In other cities, the regulatory law required by these two articles, called Estatuto da Cidade, or the City Bill, was approved in 2001. 
The Sao Paulo Master Plan, approved in 2002, incorporated all the instruments provided by Estatuto da Cidade. Urban operations were the only instrument possessed by the city for controlling urban development prior to the approval of the 2002 master plan. The new master plan consolidated four urban operations created prior to its approval, and created nine more. An urban operation is an instrument for structural transformation of any city area through a public-private partnership. It identifies a large city area in need of infrastructure improvements. Urban interventions that comply with the city master plan and municipal urban policy are then defined. These interventions presuppose mid- and long-term management measures, such as a new urban plan for the area, land readjustment (especially in slum areas), public space improvements, and analysis of real estate potential and land use requirements. The funds required for these urban interventions are procured from the incremental value realized by zoning changes to floor area ratio (FAR) permit increases and changes of usage. The extent of such increases and changes is determined by assessing existing and future urban infrastructure requirements, and the capacity of the area to generate investments to fund the infrastructure. Individuals owning property within the urban operations boundary can submit development proposals that require changes in FAR or land use. These proposals are reviewed by the city for suitability from urban and architectural standpoints and, if approved, the value increment is determined. Every urban operation has different instruments to share this value with the public sector. The commonly used methods are payment of a specific increment percentage by the developers to the public sector, or by selling certificates of potential additional construction (CEPACs). Each plot in an urban operation is linked to a specific urban intervention and the revenue obtained from the incremental value of that plot is used to fund that specific intervention.

CEPACs are a public policy instrument to capture value from projects undertaken by private developers. They are essentially economic compensation paid by the developer to the public sector for new building rights. The instrument was first created and included in the Faria Lima urban operations in 1995, but began to operate only in 2004 after the Estatuto da Cidade 2001 enabled use of CEPACs in all cities in Brazil. The city hall issues CEPACs through its agency, Empresa Municipal de Urbanizacao (Municipal Company of Urbanization) (EMURB). Banco do Brazil, a federal bank electronically auctions CEPACs in the Sao Paulo stock market (Bovespa). The amount of CEPACs issued is specified in the urban operations law and depends on the total additional area each urban operation can support. This is determined by an analysis of existing infrastructure and additional works that will be financed from funds derived from selling CEPACs. EMURB is the agency responsible for issuing CEPACs and linking infrastructure investments to each CEPAC auction. The agency disburses information about auctions and manages the overall investment program within each urban operation. The actual auctions are carried out by Caixa Economia Federal and Banco do Brazil, since CEPACs are financial instruments, and the real estate market needs reliable issuers.

All CEPACs issued in one urban operation have the same face value but correspond to different building potentials (expressed in square meters). The building potential assigned to each CEPAC is determined by the value of land to which that CEPAC is linked. For instance, a CEPAC that gives the developer the right to build on a prime piece of land will have a lower development potential associated with it compared to a CEPAC linked to a cheaper area. The final prices of CEPACs can increase in auctions depending on market demand. Each CEPAC specifies:

(i) the urban operation where the CEPACs can be used;

(ii) the intervention to be financed by the income produced;

(iii) the total value of the issue;

(iv) the price of each CEPAC;

(v) the amount issued; and

(vi) the coefficient of conversion in the event CEPACs are used for changes in use rather than for additional building area. 
Box 3 continued

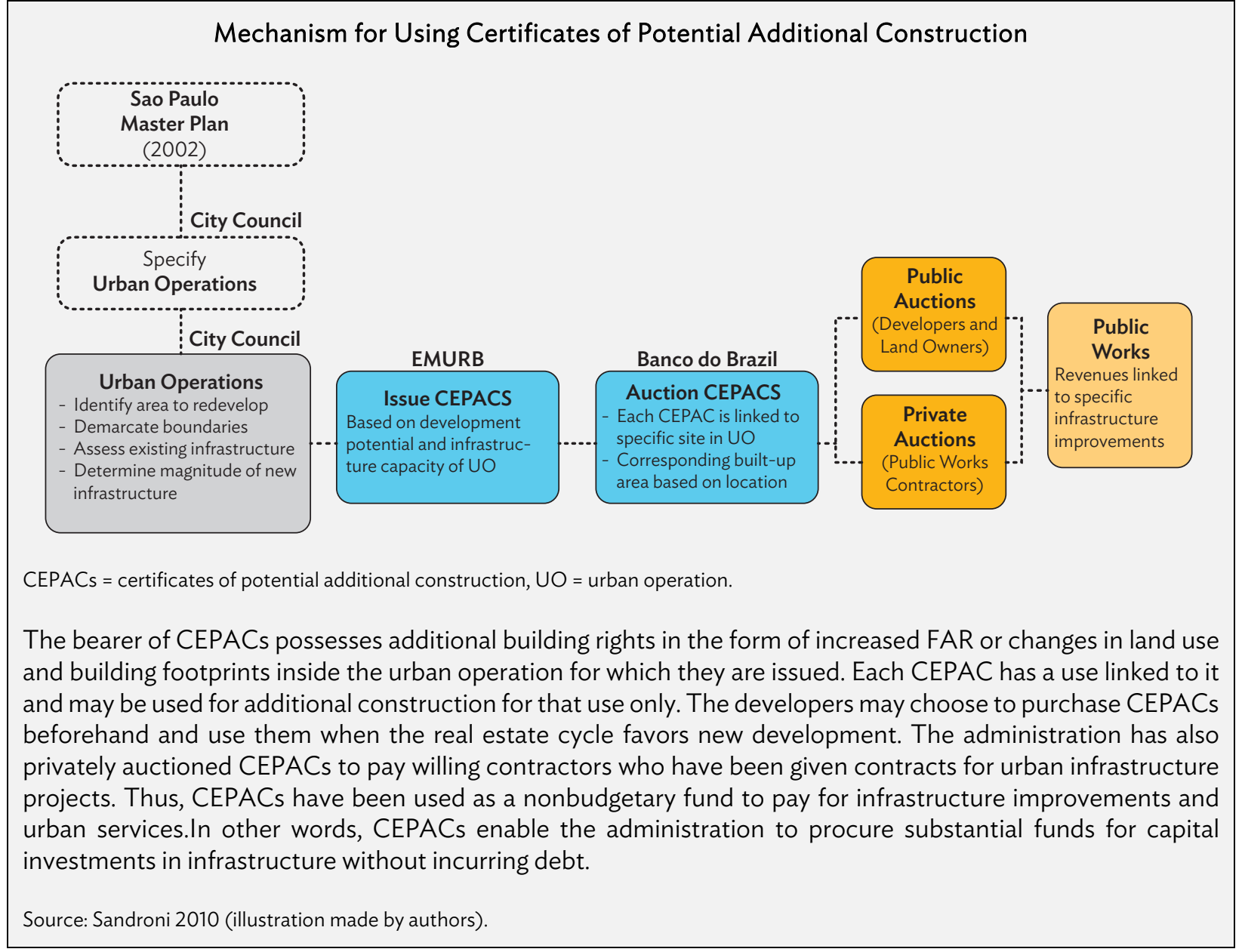

\section{POLICY AND REGULATORY CONTEXT OF URBANIZATION IN INDIA}

30. Postindependence, several policies were introduced in the country, which had a significant impact on development in urban areas. Policies such as the Urban Land Ceiling Regulation Act 1976 and rent control acts coupled with zoning practices placed restrictions on development of Indian cities. These restrictions were justified by citing the limited capacity of urban infrastructure in the cities and their inability to support more density (World Bank 2013). However, the impact of such policies were lower municipal revenues from low assessed value of land, corresponding taxes, and development fees. More importantly, they have been instrumental in shaping spatial growth patterns, and the built form. This section discusses three key pieces of legislation that have affected the trajectory of urban growth enormously in cities in India. It also provides insights on major national-level urban development initiatives undertaken by the government starting mid-2000s that have greatly influenced the urbanization discourse in the country.

\section{A. The Urban Land (Ceiling and Regulation) Act, 1976}

31. The Urban Land (Ceiling and Regulation) Act (ULCRA), was a regulation on possession of vacant urban land by a single entity that restricted the availability of land for development in cities in India, limiting 
urban growth. ULCRA was a national act passed during the National Emergency in 1976 with the intention of ensuring equitable distribution of land in urban agglomerations. A ceiling was imposed on the possession and ownership of vacant land in urban areas. The provisions of the act enabled state governments to acquire land exceeding the ceiling by payment of compensation, to dispose of the land for the common good, and to grant exceptions for certain specific categories of vacant land (JNNURM Primer). The primary objectives of this act were to prevent the concentration of valuable urban land in the hands of the few, prevent speculation and profiteering, and facilitate the availability and affordability of urban land by increasing market supply (Bakore 2007) (JNNURM Primer).

32. This act came into force in 1976 in 64 urban agglomerations spread over Andhra Pradesh, Gujarat, Haryana, Himachal Pradesh, Karnataka, Maharashtra, Orissa, Punjab, Tripura, Uttar Pradesh, West Bengal, and all the Union Territories and covered towns with a population of more than 200,000 based on the 1971 Census (JNNURM Primer). The act was subsequently adopted in Assam, Bihar, Madhya Pradesh, Manipur, Meghalaya, and Rajasthan. The state of Tamil Nadu had its own act, known as the Tamil Nadu Urban Land (Ceiling and Regulation) Act, 1978 (Bakore 2007). A land ceiling of 500 square meters $\left(\mathrm{m}^{2}\right)$ per owner was imposed in "A" class cities such as Delhi, Mumbai, and Kolkata. Land owned above this limit could be used only for construction of houses for the poor on a part of it. In category "B" cities, the ceiling was $1,000 \mathrm{~m}^{2}$; for "C" it was 1,500 $\mathrm{m}^{2}$, and D cities had 2,000 $\mathrm{m}^{2}$ (Bakore 2007).

33. The total vacant land that exceeded the ceiling limits set by ULCRA was estimated to be about 220,674 hectares. Owing to numerous exemptions, state governments could acquire only a fraction of this land, of which an even smaller fraction was put to the use it was acquired for (Bakore 2007). The failure of the act can be attributed to numerous factors. State governments had discretionary powers to grant exemptions under the provisions of the act. Compensation to landowners for surrendering excess land was far below the market rate, which discouraged them from disclosing excess land. The act itself did not make the provision of public housing mandatory. Even though state governments acquired considerable land, they did not construct a proportionate number of houses for the poor. In fact, ULCRA exacerbated issues that it was intended to solve. It held back development by creating a severe scarcity of buildable land in Indian cities, leading to a significant increase in land prices, and making it challenging for private developers to undertake development initiatives that were economically feasible. Moreover, low quantities of housing stock created a shortage of affordable housing.

34. The Government of India repealed this act by passing the Urban Land (Ceiling and Regulation) Repeal Act in 1999. The repeal was one of the mandatory reforms for states to procure funding under JNNURM.

\section{B. Coastal Regulation Zone Notification, 1986}

35. India regulates development on land-abutting water bodies by designating coastal regulation zones (CRZ). Coastal cities and urban areas in the vicinity of rivers, lakes, etc. need to develop land use plans that restrict development by maintaining low floor area ratio (FAR). The Ministry of Environment, Forest, and Climate Change notified CRZs that under the Environment Protection Act of 1986 (modified in 2011), development and other specified activities are restricted in stipulated areas. Coastal Zone Management Authorities have been established in every relevant state to monitor and regulate development in notified zones. Coastal stretches within 500 meters $(\mathrm{m})$ of the high-tide line on the landward side of water bodies are classified into four CRZ categories. Coastal stretches in urban areas that abut rivers or oceans mostly fall under CRZ Category II. Stretches which are ecologically sensitive, such as mangroves and wetlands, are categorized as CRZ Category I. CRZ I areas are usually no- 
development zones, while limited development is permitted in CRZ II areas, subject to existing FAR regulations in state Town Planning Acts. CRZ regulations strictly regulate high-density development in cities abutting water bodies. Mumbai is a classic case-geographical constraints, coupled with development restrictions such as CRZ, have caused the city to expand northwards.

\section{Rent Control Acts}

36. Rent control has been key to land use legislation since colonial times, and it has limited the availability and growth of affordable housing in urban areas, resulting in deterioration of the building stock in many cities. Legislation for rent control in India can be classified into: (i) acts passed during the colonial era and (ii) postindependence acts passed by state governments. The first rent-control legislation in India was introduced in 1918, after World War I, in Mumbai (Bombay), where it was in force until 1928. Similar legislation was subsequently adopted in West Bengal in 1920, Delhi in 1939 and in other states soon after (Dev and Satvik 2006). Post-World War II, fearing a pseudo-scarcity of rental housing due to soaring rents, the Bombay government passed the Bombay Rents, Hotel, and Lodging House Rates Control Act 1947, which froze rents in all tenanted properties and permitted only regulated and marginal increases in rent. The rent control acts were preliminary meant for two reasons: (i) to prevent rents from increasing beyond the limit set by the Rent Controller and (ii) to prevent forceful eviction of tenants by landlords. The standard fixed rent was based on the cost of construction and the market value of the property (Alok and Vora 2011). Postindependence, rent control came under the jurisdiction of state governments. The acts, which were meant to be a temporary measure to maintain rents at affordable levels, continued as policy with some amendments. Although socioeconomic conditions have changed significantly, few efforts were made to revise this legislation to reflect changing market trends. Meanwhile, consensus continues to remain elusive, even though the acts are now interpreted more in favor of tenants than was initially intended (Alok and Vora 2011).

37. Continued implementation of unrevised rent-control legislation has affected the supply of rental housing in most cities in the country. Owning rent-controlled property has become a liability for landlords as property maintenance costs have escalated over the years due to inflation and other factors, and low rents are insufficient to cover them. Building maintenance has been neglected, and thousands of rent-controlled buildings have become dilapidated. Rent control has also distorted city rental housing markets. After the act was introduced, investment in rental housing dwindled. Additionally, due to lack of public investment in housing schemes, affordable housing in cities is in short supply, and the disparity between supply and demand has made new, market-rate rental housing extremely expensive (Shenvi 2014). Over the years, tenants of some rent-controlled tenements have become affluent, but still continue to pay low rents in prime areas of the city. Low rents affected buildings and discouraged landlords from renting out apartments to people who truly need rentcontrolled housing (Shenvi 2014). Rent control has also eroded municipal revenues. Numerous urban local bodies (ULBs) collect property taxes based on the "ratable value," or rent collected from a property. Buildings with frozen rents have very low ratable values, resulting in low property taxes. Quite a few of these properties are located in central city areas, where market rents are very high. Thus, ULBs are losing considerable revenue from properties that could otherwise generate sizeable property taxes, while having to provide the same urban services to new and rent-controlled properties alike.

38. In 2011, the Ministry of Housing and Urban Poverty Alleviation, proposed the draft "Model Residential Tenancy Act, 2011." The ministry estimated a housing shortage of around 25 million countrywide, and-by making a provision for increase in rentals through the legislation-it hoped to encourage property owners to rent out their properties and ease the shortfall. Although rent control falls under state jurisdiction, 
the central government sought adoption of the draft model by mandating that only states that pass the law would be eligible for funding under the flagship Rajiv Awas Yojana, an affordable housing initiative. The new act established a framework for regulation of residential tenancy and for balancing the rights and responsibilities of landlords and tenants (Shenvi 2014). It has been formally adopted by the states of Karnataka, Rajasthan, Maharashtra, and West Bengal (Alok and Vora 2011).

\section{Current Zoning Practices in Major Metropolitan Cities}

39. Cities in India regulate urban development through the creation of a city development plan, and development control regulations for each city under provisions of Town and Country Planning Acts adopted at state level. Both planning instruments specify permissible built-up areas and plot-by-plot usage. Urban form is regulated by specifying the permissible FAR of every plot, putting a limit on the built-up space created, and/or by specifying setbacks and building heights based on the plot size and widths of abutting streets. In some cities, a combination of the two is also used.

40. A common planning practice in cities in India has been to reduce congestion in central city areas by zoning them for low FARs. In cities like Mumbai and Kolkata, the FARs permitted during the colonial period were much higher than those permitted today. Starting 1964, FAR in Mumbai has been gradually reduced by a 1991 policy that set the maximum permissible FAR at 1.33, and 1 in the Island City and the suburbs, respectively. Higher FAR has been permitted in isolated pockets outside the Island City to absorb the excess development rights generated by the city's transfer of development rights policy (Bertaud 2011). The latest development plan proposed a blanket FAR of 2 citywide. Chennai classified buildings into three categories: ordinary buildings, special buildings, and multi-story buildings, based on building height, density and commercial activities. Permissible FAR ranges from 1.5 for ordinary buildings to 2.5 for multistory buildings - permissible FAR for multistory buildings is 2.5 for plots of up to 1,500 $\mathrm{m}^{2}$, scaling down to 2 for larger plots (Karteek 2015). Chennai also has a provision for premium FAR, the percentage of which is determined by the width of the abutting street. Bangalore has an FAR variation between 1.5 to 2.5 based on road widths and the independence of plot sizes. FAR is calculated based on plot coverage for uses such as group housing, row houses, industrial buildings, and IT-related uses. The city also permits an additional FAR of 0.5 on plots abutting streets with widths of $60 \mathrm{~m}$ or more within a 150-meter radius of any transit hub (Karteek 2015). Hyderabad regulates built-up areas on the basis of setbacks, widths of adjacent roads and controls for fire safety and air-traffic clearance. Theoretically, there are no height restrictions for buildings abutting streets wider than $30 \mathrm{~m}$ (Singh 2015). FAR norms in Delhi are based on type of building activity, plot size, and parking standards. For residential development, FAR decreases as plot size increases. Delhi permits redevelopment of a minimum area of 4 hectares using a FAR of 4 (Karteek 2015). In 2015, the Ministry of Urban Development approved a Transit-Oriented Development (TOD) Policy that facilitates higher FAR and building heights within $500 \mathrm{~m}$ of mass rapid transit systems such as metro and bus rapid transit systems (BRTS) in Delhi. The Delhi Development Authority (DDA) formulated TOD Guidelines and integrated them in its Delhi Master Plan-2021. Through this policy, the DDA designated a 2,000-meter wide belt from the centerline of Mass Rapid Transit (MRT) corridors in the city as TOD influence zones. Delhi's TOD policy is expected to facilitate redevelopment, and retrofit of existing urban neighborhoods using higher FARs, fostering compact, mixed-use development along MRT corridors in the city. 
Table 1: City Center Floor Area Ratio Values in Different Cities

\begin{tabular}{lr}
\hline City & \multicolumn{1}{c}{ FAR } \\
\hline Sao Paulo & 1.00 \\
Mumbai & 1.33 \\
Chennai & 1.50 \\
Delhi & $1.20-3.50$ \\
Amsterdam & 1.90 \\
Venice & 2.40 \\
Paris & 3.00 \\
Shanghai, China & 8.00 \\
Vancouver & 9.00 \\
San Francisco & 9.00 \\
Chicago & 12.00 \\
Hong Kong, China & 12.00 \\
Los Angeles & 13.00 \\
New York & 15.00 \\
Denver & 17.00 \\
Tokyo & 20.00 \\
Singapore & $12.00-25.00$ \\
\hline
\end{tabular}

Source: World Bank (2013)

\section{E. Socioeconomic Impacts of Restricting Density}

41. Land use policies that limit the development potential of urban areas have drastically reduced per capita consumption of land in Indian cities. Households in Mumbai, which has a density equivalent to New York City, consume only $2.9 \mathrm{~m}^{2}$ of floor space per person, which is one of the lowest residential floor areas per person anywhere in the world (Sridhar 2010). Low FAR caused a steep increase in property prices in central areas of cities. Redevelopment of old buildings is no longer feasible as these buildings were built prior to the imposition of development restrictions and already have greater FARs than permitted by current regulations. Such restrictions on development led to dilapidation of old housing stock and created a shortage of affordable housing. Only the affluent can afford to buy houses in these areas, while middle- and low-income households have been priced-out from the city center to the urban peripheries. Policies that encourage sprawl are economically inefficient as they necessitate increased public investment in widespread infrastructure networks (Bertaud 2002) and result in longer commute times. A study revealed consumer loss from FAR restrictions in Bangalore represented 3\%$6 \%$ of household incomes (Bertaud and Brueckner 2004). Additionally, due to lack of affordable housing options, informal settlements such as slums proliferated in urban areas. Paradoxically, the densities in these settlements are much higher than those permitted under the development regulations. As a result, even though built-up areas in cities have been restricted through low FAR, the demand for urban services has consistently increased with increasing population density.

42. A compact urban form that promotes walkability and reduces commuting time is one of the prerequisites for urban economic development (UN-Habitat 2014). For this reason, redevelopment of deteriorating, low-density urban areas into compact, high-density, and mixed-use neighborhoods, by permitting FAR variations through zoning granularity, (such that higher FARs are permitted in zones such as business districts, transit hubs, etc. and FARs reduce gradually as one moves away from such uses), is imperative to rejuvenate cities in the country. Delhi's TOD policy is a step in the right direction, and it is essential for other metropolitan cities in India to develop policies and regulations that integrate 
this approach for sustainable growth. Moreover, it is also crucial to understand the potential of high FAR to stimulate development and formulate implementation mechanisms.

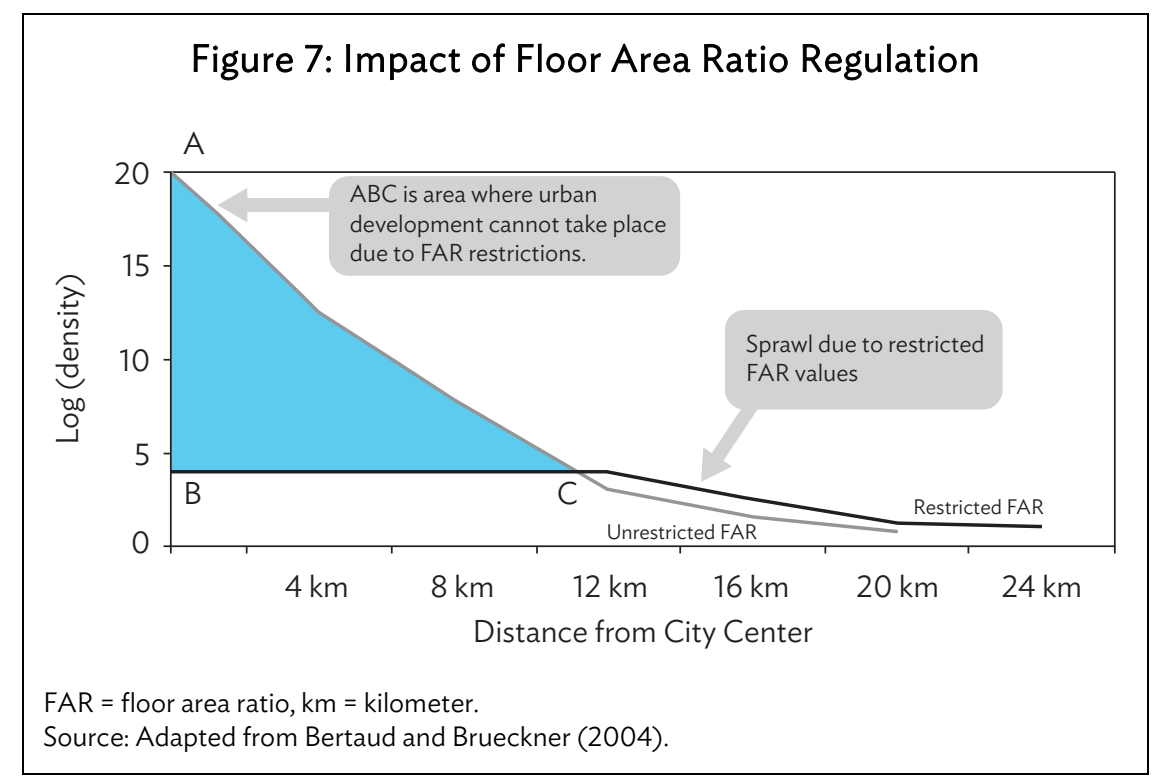

\section{F. The Jawaharlal Nehru National Urban Renewal Mission}

43. Until the early 2000 s, central government policies mainly focused on rural and agricultural development in the country. Although states and cities undertook a number of urban development programs, national level programs mainly focused on provision of basic services to urban areas. In 2005, a countrywide initiative was introduced that provided funds for comprehensive urban development through augmentation of urban infrastructure and services. Cities could access these funds only after preparing a city development plan and implementing a series of urban reforms.

44. In 2005, the central government introduced JNNURM with a view to encourage planned urban development over a 7-year period. This was later extended to 2014. The program envisaged a disbursement of $\$ 20$ billion as grants to qualifying cities. In accordance with the 74 th constitutional amendment, which called for devolution of powers to ULBs, cities had to undertake 13 reforms to qualify for funding, such as repeal of ULCRA, increase accountability of ULBs and parastatal agencies by making information publicly available, and make administration transparent through e-Governance strategies to name a few examples. JNNURM disbursed central government funds to ULBs for planning and implementing reforms in governance, and for projects to improve urban infrastructure, service delivery, and provision of basic services to the urban poor. JNNURM's project-based approach required approvals for individual projects from the central government. Of the 63 qualifying cities, only 20 could fully utilize funds disbursed through this program. Subsequently, most of the prerequisites were diluted, since the ULBs did not possess the capacity to carry out reforms. Few cities were able to fully implement projects sanctioned under JNNURM due to its fragmented approach, and due to ULBs' lack of technical expertise and capacity. 


\section{G. The Smart Cities Mission}

45. In 2014, several new urban development schemes were announced. The first of these-the Heritage City Development and Augmentation Yogana-was launched in January 2015 for holistic development of heritage cities such as Varanasi and Kanchipuram. In June 2015, the Government of India simultaneously launched Atal Mission for Rejuvenation and Urban Transformation (AMRUT), the Smart Cities Mission, and the Housing for All Scheme (Urban). Initiated by the Ministry of Housing and Urban Poverty Alleviation, the Housing for All Scheme-or Pradhan Mantri Awas Yojana-aims to provide housing to all economically weak households in cities in India by 2022. The guidelines enumerate four different approaches through which affordable housing can be created. The Smart Cities Mission and AMRUT are under the MoUD. The primary objective of AMRUT is to provide basic services such as water supply, power, and sewerage to every household in 500 Indian cities. Unlike JNNURM's project-based approach, AMRUT requires that states prepare annual action plans, involving states in planning and implementation of projects, and developing the administrative and technical capacities of ULBs. Capacity building is a major component of this program, and AMRUT will complement the Smart Cities Mission.

46. The Smart Cities Mission focuses on sustainable and inclusive development in compact areas that can be used as replicable models for other cities. ${ }^{2}$ The mission objective is to develop core infrastructure in 100 cities, improve the quality of life of their citizens, and promote sustainable practices using information communication technology (ICT)-based solutions. Each of the selected cities prepared a Smart City Plan that consists of one ICT-based pan-city initiative and one area-based development proposal.

47. The pan-city initiative comprises the application of selected smart solutions to existing citywide infrastructure networks and transit systems. E-Governance, water management, waste management, energy management, and urban-mobility initiatives, such as smart parking, and intelligent traffic management, are some of the potential solutions outlined in the mission guidelines. Additionally, application of such smart solutions will involve the use of technology, information, and data to make infrastructure and services better. ${ }^{3}$

48. The key objective of area-based development under this mission is to transform existing urban areas by promoting mixed-use, walkable, and transit-accessible inclusive neighborhoods, with open spaces and cultural amenities that use urban land efficiently through good planning and improve the overall quality of life. The guidelines enumerate three area-based development approaches: (i) area improvement (retrofitting), (ii) city renewal (redevelopment), and (iii) city extension (greenfield), or a mix of all three. ${ }^{4}$ MoUD cited the Bhendi Bazar Redevelopment Project in Mumbai ${ }^{5}$ and the Ahmedabad Local Area Improvement Plan, both of which use FAR incentives for redevelopment of a core urban neighborhood, as recommended approaches for retrofit and redevelopment.

49. Since 2005, national urban development programs evolved from initiatives targeting urban infrastructure projects (water supply, sanitation, roads, etc.) to programs that require ULBs to plan for cities more holistically. The area-based development approach advocated in the Smart City Mission is the need of the hour. However, given the limited funding available and current scope of carrying out

\footnotetext{
Smart Cities Mission. www.smartcities.gov.in.

Footnote 2.

Footnote 2.

Footnote 2.
} 
such projects in only one neighborhood in each city, mainstreaming this development approach will take time. There is a need to examine the recommended approaches to assess their adaptability to the varied urban contexts in the country.

\section{CASE STUDIES: AREA-BASED REDEVELOPMENT APPROACHES IN INDIA}

50. This section examines the Bhendi Bazaar Redevelopment Project in Mumbai, and the Ahmedabad Local Area Improvement Plan as in-depth case studies and highlights their advantages as well as pit-falls.

\section{A. Cluster Redevelopment in Mumbai}

51. Mumbai was the first city in India to use floor area ratio (FAR) incentives to stimulate urban redevelopment. Urban redevelopment policy was a function of development control regulations (DCRs) that came into force in 1991. Over the last 2 decades, this policy has continued to evolve to reduce loopholes and optimize city development potential. In recent years, Mumbai has also integrated a cluster redevelopment approach-with mixed outcomes. The policy is enabling legislation for the Bhendi Bazaar Redevelopment Project.

52. A major percentage of buildings in Mumbai, particularly the Island City, was built in the 19th and early 20th centuries and came under the jurisdiction of the Bombay Rent Control Act of 1947. As discussed previously, rents for these buildings were not revised in correlation with inflation and were unable to cover the expenses for periodic maintenance and repairs, resulting in their deterioration.

Table 2: Urban Profile of Greater Mumbai

\begin{tabular}{ll}
\hline Area & $603 \mathrm{~km}^{2}$ \\
\hline Population (2011) & $12,478,447$ \\
\hline Population Density (2011) & 21,000 persons $/ \mathrm{km}^{2}$ \\
\hline GDP & $\$ 209$ billion \\
\hline $\begin{array}{l}\text { GDP = gross domestic product, } \mathrm{km}^{2}=\text { square kilometer. } \\
\text { Source: Municipal Corporation of Greater Mumbai, PriceWaterhouseCoopers; Census } \\
\text { of India. }\end{array}$
\end{tabular}

53. Dilapidation of building stock. In 1968, the State Government of Maharashtra established the Bedekar Committee to assess the condition of such properties. The government recognized the inability of landlords of rent-controlled properties to maintain their properties, and passed the Bombay Building Repairs and Reconstruction Act in 1969 on the recommendation of the Bedekar Committee. This Act facilitated the formation of the Bombay Building Repairs and Reconstruction Board-now the Mumbai Building Repairs and Reconstruction Board (MBRRB)-in 1971, and classified old and dilapidated buildings into three categories based on their date of construction (Table 3 ) to collect a repair cess (tax). There were 19,642 such properties in the city. ${ }^{6}$ The cess amount was calculated on the basis of the construction date and rent paid by the tenants. The landlord collected the cess from the tenants and submitted it to the government. The Maharashtra Housing and Area Development Authority

6 Maharashtra Housing and Area Development Authority. www.mhada.maharashtra.gov.in 
(MHADA) was set up in 1977 under the provision of an Act of the same name passed by the state government in 1976.

Table 3: Classification of Cess Properties in Mumbai

\begin{tabular}{lccc}
\hline Category & $\begin{array}{c}\text { Year of } \\
\text { Construction }\end{array}$ & $\begin{array}{c}\text { Number of Cess } \\
\text { Buildings }\end{array}$ & $\begin{array}{c}\text { Cess Buildings as } \\
\text { of March 2008 }\end{array}$ \\
\hline A & $\begin{array}{c}\text { Prior to } \\
\text { September 1940 }\end{array}$ & 16,502 & 13,360 \\
\hline B & $\begin{array}{c}\text { 1 September } \\
\text { 1940 to 31 } \\
\text { December1950 }\end{array}$ & 1,489 & 1,474 \\
\hline C & $\begin{array}{c}\text { 1 January 1951 to } \\
\text { 30 September } \\
\text { 1969 }\end{array}$ & 1,651 & 1,270 \\
\hline TOTAL & & 19,642 & 16,104 \\
\hline
\end{tabular}

Source: Maharashtra Housing and Area Development Authority.

54. MHADA was assigned the task of carrying out structural repairs on old, rented buildings. However, owing to lack of funds and bureaucratic hurdles, MHADA only undertook repairs of extremely dilapidated buildings. The maintenance of all other properties continued to be ignored (Patel 2004). According to the provisions of the MHADA Act of 1976, highly dilapidated buildings could be classified as "beyond economic repair." MBRRB, now a part of MHADA, carried out reconstruction of such properties. The landlord and tenants were housed in transit camps during reconstruction, and were given ownership units in reconstructed buildings upon contributing to the cost of construction. By the late 1980s, it was evident that the MBRRB did not possess the funds or capacity to reconstruct the large number of dilapidated buildings in the city.

55. In the late 1980s, in the wake of deindustrialization and neoliberal reforms, Mumbai's political landscape witnessed a major transformation (Weinstein 2014). Urban development took center stage for the first time since independence, and paved the way for real estate and commercial development in Mumbai. In 1991, the Greater Mumbai Development Control Regulations (DCRs) were framed under Section 31(1) of the Maharashtra Regional and Town Planning Act, 1966. Section 33 of these regulations deals with allowing additional FAR. Subsection 33(7) of these regulations facilitates redevelopment of cess properties by landlords and tenants by forming cooperative housing societies. Initially, the permissible FAR was 2, or that occupied by the existing structure, whichever was more, to facilitate redevelopment. Subsection 33(9) of these regulations enabled MHADA, MBRRB, or MCGM to undertake repairs and reconstruction of cess buildings, or urban renewal schemes in the Island City, using 2.4 times the permissible FAR.

56. Development control regulations. DCR 33(7) received a very lukewarm response, leading to the establishment of the Sukhtankar Committee in 1996, which reassessed the condition of cess properties in the Island City, and the status of implementation of DCR 33(7). In accordance with the committee's recommendations, DCR 33(7) was amended in 1999 to enable the provision of incentive FAR for redevelopment. This amendment enabled landlords to collaborate with private developers to invest in redevelopment of their properties. Consent of $70 \%$ of the tenants was required to initiate the redevelopment process. In case of Category A cess buildings, the minimum permissible FAR was 2.5, but 
the final FAR was based on the area required to rehouse all existing tenants. The permissible FAR for redevelopment of Category $B$ cess buildings was based on the built-up area required to rehouse all existing tenants plus $50 \%$ incentive. For extremely dilapidated Category $C$ buildings, an FAR similar to Category A was permissible to speed up the redevelopment process. The policy also facilitated redevelopment of two or more plots through composite redevelopment with higher incentives (Table 3).

57. The minimum size of new units was restricted to $30 \mathrm{~m}^{2}$. Beyond this, tenants were given as much area as initially occupied by them up to a maximum of $75 \mathrm{~m}^{2}$. Above this, the tenants were required to pay construction costs on a fractional basis. The developer was given $50 \%$ of the base rehabilitation area (30 $\mathrm{m}^{2}$ of the area occupied by tenant in the original building) as an incentive built-up area that could be sold at the market rate to cover construction costs and make the project attractive for investment. Postredevelopment, the developer was to hand over the property to a cooperative housing society, comprising the landlord, the original tenants, and the new inhabitants who have purchased the saleable units at the market rate. The DCR also specified setbacks from the street and adjoining structures, as well as strict open-space requirements. Buildings exceeding a height of $24 \mathrm{~m}$ will have to integrate fire safety features as specified in the DCR.

Table 4: Floor Area Ratio for Redevelopment of Two or More Plots under DCR 33(7)

\begin{tabular}{ll}
$\begin{array}{l}\text { Number of Plots for Composite } \\
\text { Redevelopment }\end{array}$ & \multicolumn{1}{c}{ Permissible FAR } \\
\hline 1 plot & $\begin{array}{l}2.5 \text { or FSI required for rehabilitation of occupiers } \\
\text { plus } 50 \% \text { incentive FSI whichever is higher. }\end{array}$ \\
\hline 2 to 5 plots & $\begin{array}{l}2.5 \text { or FSI required for rehabilitation of occupiers } \\
\text { plus } 60 \% \text { incentive FSI whichever is higher. }\end{array}$ \\
\hline 6 or more plots & $\begin{array}{l}2.5 \text { or FSI required for rehabilitation of occupiers } \\
\text { plus } 70 \% \text { incentive FSI whichever is higher. }\end{array}$ \\
\hline FAR = floor area ratio, FSI = floor space index. & \\
Source: Maharashtra Housing and Area Development Authority (MHADA). https://mhada.maharashtra.gov.in/
\end{tabular}

58. DCR 33(9), a government ordinance in 2008, stipulated that if the repair costs of a cess building exceed Rs 2,000 per square foot of its built-up area, the tenants and the landlord will pay the excess cost to MHADA to undertake repairs - failing which, the property will be declared "beyond economic repair" and proposed for redevelopment. DCR 33(9) had been amended in 1999 to enable "cluster redevelopment" of a group of such dilapidated buildings occupying a minimum area of $4,000 \mathrm{~m}^{2}$ or 1 acre. The permissible FAR was 4, or the FAR required for rehabilitation of existing tenants or occupants, whichever was more, plus incentive FAR. Slum settlements were also included in the scheme, provided they did not occupy more than $25 \%$ of the total area of the cluster. Cluster redevelopment schemes can be undertaken by MHADA and MCGM departmentally, or in collaboration with another suitable agency. MHADA can collaborate with landowners, a housing society of occupiers and developers, or a housing society of hutment dwellers. Additionally, these schemes can be undertaken independently by landowners, or housing societies of occupants or developers. The percentage of FAR incentive granted was determined by the total area of amalgamated plots-i.e., the overall area of the cluster (Table 5). 
Table 5: Incentive Floor Area Ratio under DCR 33(9)

\begin{tabular}{lc}
$\begin{array}{l}\text { FAR Incentive } \\
(\%)\end{array}$ & $\begin{array}{c}\text { Area of Amalgamated Cluster } \\
\left(\mathrm{m}^{2}\right)\end{array}$ \\
\hline 55 & 4,000 to 8,000 \\
65 & 8,001 to 12,000 \\
70 & 12,001 to 16,000 \\
75 & 16,001 to 20,000 \\
80 & Above 20,000 \\
\hline \multicolumn{2}{l}{ FAR = floor area ratio. } \\
Source: Development Control Regulations of Greater Mumbai.
\end{tabular}

59. According to the cluster redevelopment mechanism, each residential occupant will be given the carpet area occupied in the old building, subject to a minimum carpet area of $30 \mathrm{~m}^{2}$. In the case of nonresidential occupants, an area equivalent to that occupied in the original building will be given. Projects jointly undertaken with MHADA or MCGM in which rehabilitated FAR exceeds 2.5 will provide $5 \%$ of the built-up area of FAR 4 to MHADA or MCGM free of cost. This area will be included in rehabilitation area and be eligible for an incentive of up to $50 \% .^{7}$ Clusters located in coastal regulation zone boundaries will have to abide by Ministry of Environment and Forests (MoEF) guidelines. A highpower committee chaired by the municipal commissioner of MCGM was established to transition proposals to approvals for redevelopment under the scheme, while also making suggestions for improvements.

60. The DCR for Greater Mumbai also introduced the concept of TDR for the first time in the city. Accordingly, the unconsumed development potential originating from any plot on the Island City can be consumed in the suburbs. Landowners were issued development right certificates, which could be sold to developers. Primarily meant to compensate owners of heritage properties for loss of in-situ development rights, this mechanism was also adopted for redevelopment projects in which the plot location did not permit use of higher FAR - for example, in coastal regulation zones.

61. The redevelopment of buildings and clusters under DCR 33(7) and DCR 33(9) received certain concessions in FAR calculations. Common areas such as corridors and staircases were FAR-exempt. Additionally, elevated features such as balconies, flowerbeds, and unusable areas were also exempt from FAR calculations. However, it was observed that the developers were charging new homebuyers based on the total built-up area (including the footprint of the walls and the FAR-exempt spaces) instead of the carpet area-the area within a unit actually available for use. This enabled the developers to exact huge sums of money from new homebuyers from areas that were potentially free of FAR. In a move to curb these unethical practices, the government introduced DCR 35(4) in January 2012 for provision of fungible FAR on payment of a premium. Developers undertaking redevelopment under DCR 33(7) and DCR 33(9) could obtain fungible FAR free of cost for rehousing existing tenants and on payment of a premium for the sale component. The percentage of fungible FAR is calculated as a percentage of the qualifying basic rehabilitated area (Table 6).

7 Mumbai Metropolitan Region Development Authority. 1991. Development Control Regulations for Greater Mumbai. (Amended up to 2009). 


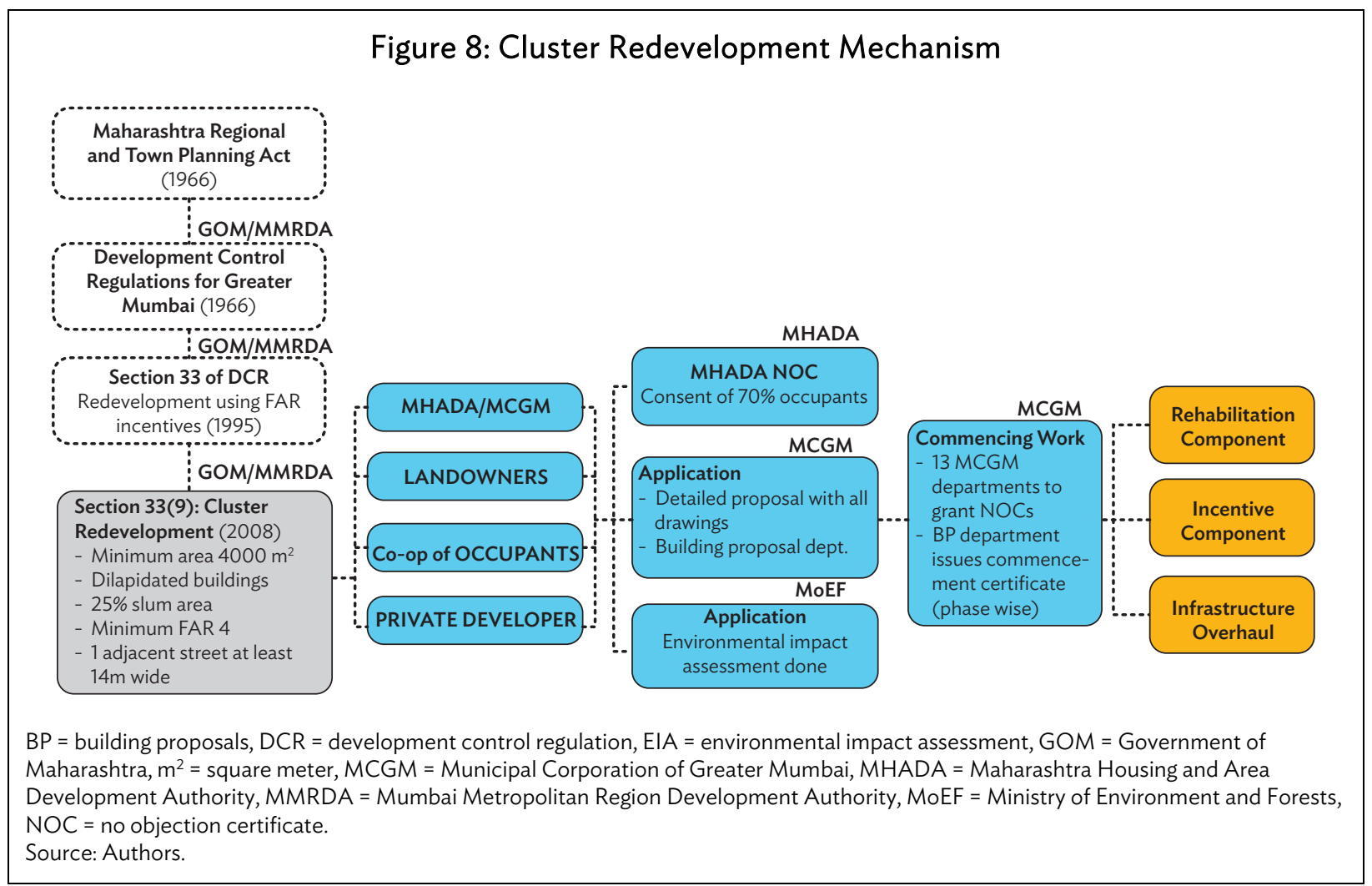

Table 6: Provision of Fungible Floor Area Ratio

\begin{tabular}{lcc}
\hline & $\begin{array}{c}\text { Fungible FAR \% } \\
\text { of rehabilitated } \\
\text { area }\end{array}$ & \multicolumn{1}{c}{ Premium to Be Paid } \\
\hline Building Use & 35 & $60 \%$ of Ready Reckoner Rate \\
Residential & 20 & $80 \%$ of Ready Reckoner Rate \\
Industrial & 20 & $100 \%$ of Ready Reckoner Rate \\
Commercial & &
\end{tabular}

$\mathrm{FAR}=$ floor area ratio.

Note: The ready reckoner rate is the rate of land or built-up area in a certain urban locality determined by the state government. The rate differs based on the location and is revised periodically.

Source: Municipal Corporation of Greater Mumbai (2012).

62. Successive modifications have been made to redevelopment policies. Currently, redevelopment under DCR 33(7) is carried out with a standard FAR of 3, and under DCR 33(9) with an FAR of 4. If the area required for rehousing tenants exceeds this, it can be obtained through the fungible FAR provision. The percentage of incentives is $50 \%$ for DCR 33(7) in accordance with the cluster area under DCR 33(9), and calculated on the basic rehabilitated area (excluding fungible FAR). Over the last few years, over 1,000 cess properties have been redeveloped under the provisions of DCR 33(7). A majority of these projects are located in $C$ and $D$ wards of the city, which have major clusters of dilapidated properties. However, the plots in these areas are quite narrow and redevelopment of individual buildings resulted in high-rise development along narrow streets with minimum setbacks. This regulation was legally challenged by filing public interest litigation that highlighted quality of life and safety concerns. 
Following the judgment of the Supreme Court of India, both sections DCR 33(7) and DCR 33(9) were amended to mandate setbacks of at least $6 \mathrm{~m}$ from the street on one side. The open space concessions have also been removed.

63. According to MCGM officials, MCGM earned considerable revenue from the sale of fungible FAR since 2012. While income from octroi was the primary revenue source of the MCGM in FY 20132014 , income from property taxes and development charges came in close second, and amounted to a considerable percentage of MCGM's revenue (Table 10).

64. Bhendi Bazaar Redevelopment Project. As the port of Bombay flourished under British rule, numerous traders and merchants from diverse communities came to establish trading markets. A multitude of migrant workers and laborers came with them, settling near the docks. The traders and migrants built residential quarters, with shops on the ground floor and residential tenements on the upper floors. Bhendi Bazaar, in the C Ward of Mumbai, abutting the J.J. Flyover and home to the Dawoodi Bohra community, is one such area. Today, Bhendi Bazaar is one of the most congested parts of Mumbai, with densely populated buildings, narrow streets bustling with activity, a lack of open spaces, and outdated urban infrastructure. Most buildings in Bhendi Bazaar are reeling under the effects of rent control and have become severely dilapidated. Recognizing the dire need to improve the lives of inhabitants of the area, the religious head of the Bohra community created the Saifee Burhani Upliftment Trust (SBUT). The aim was to transform Bhendi Bazaar into a vibrant residential and commercial space with modern civic amenities and open spaces. SBUT undertook the ambitious task of redeveloping more than $65,000 \mathrm{~m}^{2}$ of the area under the cluster redevelopment scheme of DCR 33(9) in July 2011.

65. The SBUT roped in local and international consultants to prepare a master plan for an area of 16 acres in Bhendi Bazaar that integrates 280 plots and 245 buildings, one of which is the Raudat Tahera, a mausoleum of the deceased religious leaders of the Bohra community. The project will rehabilitate 3,200 families and 1,250 commercial establishments, affecting almost 20,000 individuals. The new layout has been divided into nine sectors and will have 17 high-rise towers with a total built up area of $126,576 \mathrm{~m}^{2}$, and an FAR of 5.98. Four of the towers will be for sale (Table 7). The first phase of the project comprises development of five sectors. The remaining sectors will be redeveloped in the second phase. An NOC was obtained from MoEF in May 2013 and the master layout was approved by MCGM's Building Proposal Department in January 2015. MCGM approved building plans for Sectors I and III and issued a commencement certificate for the start of construction in Sector III.

66. Obtaining the consent of occupants was a long process, and the most challenging aspect of the project. As of this paper's writing, $85 \%$ of plot owners and $77 \%$ of the tenants provided their consent, and MHADA certification has been obtained for $80 \%$ of occupants. The SBUT built temporary accommodation for 750 residential tenants at Anjirwadi. Mufaddal Shopping Centre, a newly constructed shopping complex in Mandvi, houses 200 commercial tenants. Transit accommodation has been constructed using an FAR of 4 and has to be torn down once the rehabilitation component of the project has been constructed to enable SBUT to take advantage of the incentive FAR. 
Table 7: Area Distribution in the New Cluster

\begin{tabular}{|c|c|}
\hline Use & Built Up Area \\
\hline Roads & $17,000 \mathrm{~m}^{2}$ \\
\hline \multicolumn{2}{|c|}{ Rehabilitation Component } \\
\hline $\begin{array}{c}\text { Commercial } \\
\text { Residential }\end{array}$ & $\begin{array}{c}32,488 \mathrm{~m}^{2} \\
130,150 \mathrm{~m}^{2}\end{array}$ \\
\hline \multicolumn{2}{|c|}{ Incentive Component } \\
\hline Incentive at $80 \%$ & $126,576 \mathrm{~m}^{2}$ \\
\hline TOTAL & $289,215 \mathrm{~m}^{2}$ \\
\hline
\end{tabular}

67. Certain land parcels in the cluster were on lease from MCGM, which did not permit the amalgamation of its leasehold land with freehold land. This land has been obtained by land swapping. Plots with reservations will be developed in line with DCR requirements. Realignment of all the infrastructure within the cluster has been completed. SBUT will undertake the reconstruction of roads in accordance with the approved layout. New sewer lines, storm water drains, and ducts for electricity and other utilities will be laid out. A new receiving station will be built and almost 1,000 new trees will be planted. The new buildings incorporate modern amenities and security measures such as surveillance cameras, fire alarms, and sprinkler networks. The rehabilitated units will be self-contained units with a minimum area of $35 \mathrm{~m}^{2}$. Sustainable practices, such as rainwater harvesting, sewerage recycling, and solar panels for lighting common areas have been integrated into the design.

68. Development charges. The MCGM levies development charges on all new construction. The proposal, comprising all layouts and plans, is first submitted to the Building Proposals Department for scrutiny. It is then forwarded to numerous MCGM departments such as the Storm Water and Drain Department, the Sewerage Department, the Environmental Department, and the Traffic and Coordination Department for their NOCs. Certain departments levy their own charges. Development charges collected by MCGM from the Bhendi Bazaar proposal amount to more than $\$ 20$ million (Table 8).

Table 8: Development Charges Paid to Municipal Corporation of Greater Mumbai for the Bhendi Bazaar Redevelopment

\begin{tabular}{lccr}
\hline \multicolumn{1}{c}{ Category } & $\begin{array}{c}\text { Rate }(\% \text { of } 2014 \text { Ready } \\
\text { Reckoner Rate) }\end{array}$ & $\begin{array}{c}\text { Total Area } \\
\left(\mathrm{m}^{2}\right)\end{array}$ & $\begin{array}{c}\text { Amount } \\
(\$)\end{array}$ \\
\hline Land & $0.5 \%$ of $\$ 1,200$ & 65,429 & 398,819 \\
Residential Area & $2 \%$ of $\$ 2,700$ & $2,56,726$ & $13,827,552$ \\
Commercial Area & $4 \%$ of $\$ 4,560$ & 32,488 & $5,925,913$ \\
\hline TOTAL & & & $20,152,284$ \\
\hline
\end{tabular}

$\mathrm{m}^{2}$ = square meter, SBUT = Saifee Burhani Upliftment Trust.

Note: The figures have been calculated on the basis of data obtained from SBUT and Ready Reckoner. They must be treated as an estimate and not the actual amount.

Source: SBUT; Ready Reckoner India. www.readyreckoner.in 
69. Property Taxes. Starting 2013, MCGM revised the property tax regime and started collecting tax on the capitalized value of the property. Previously, taxes were collected on the ratable value (rentgenerating capacity) of the property, with the result that taxes collected from rent-controlled properties were negligible. Tax relief is available in the form of reduced property taxes for rehabilitated occupants of properties redeveloped under DCR 33(7) and 33(9) (Table 9), whereas new home buyers have to pay applicable property taxes. Thus, even though the tax rebate costs MCGM significant revenues, property taxes earned after redevelopment are much higher than those obtained from rent-controlled properties.

Table 9: Property Tax Schedule for Rehabilitated Occupants

\begin{tabular}{ll}
\hline Period & \multicolumn{1}{c}{ Rate } \\
\hline 1st to 10th year & 20\% of property tax levied in that particular year \\
11th to 15th year & $50 \%$ of property tax levied in that particular year \\
16th to 20th year & 80\% of property tax levied in that particular year \\
\hline
\end{tabular}

Source: MCGM (1997).

70. All in all, MCGM earned significant revenue in the form of development charges from this proposal, and property taxes generated once this project is complete will be higher again. Additionally, SBUT is undertaking a complete overhaul of the civic services within the cluster at a cost of millions of Indian rupees - a task that would otherwise have been carried out by MCGM. Thus, this project will not just generate considerable revenue, but also create local infrastructure without any cost to the MCGM.

71. Summary of case findings. As of today, the Bhendi Bazaar Project is the only redevelopment project being implemented under Mumbai's Section DCR 33(9). The project has been in the pipeline for several years and faced numerous policy and social roadblocks. However, the revenue generated by the project through development charges amounts to 5\% of MCGM's overall income from such charges. The impact on property taxes cannot be assessed, as the project has not yet been constructed. Key findings are shown in Table 10.

Table 10: Municipal Corporation of Greater Mumbai Income in 2013-2014 (\$ million)

\begin{tabular}{lr}
\hline Income Source & Revenue \\
\hline Octroi and Toll & $1,035.0$ \\
\hline Development Charges & 427.0 \\
Development Charges & 74.0 \\
Premium FAR & 38.5 \\
Fungible FAR & 292.0 \\
\hline Property Tax & 150.0 \\
\hline TOTAL INCOME & $3,574.0$ \\
\hline
\end{tabular}

FAR $=$ floor area ratio.

Note: Revenue does not include development charges generated by the Bhendi Bazaar Project, which are a part of the 2014-2015 budget.

Source: Municipal Corporation of Greater Mumbai Budget 2013-2014. 


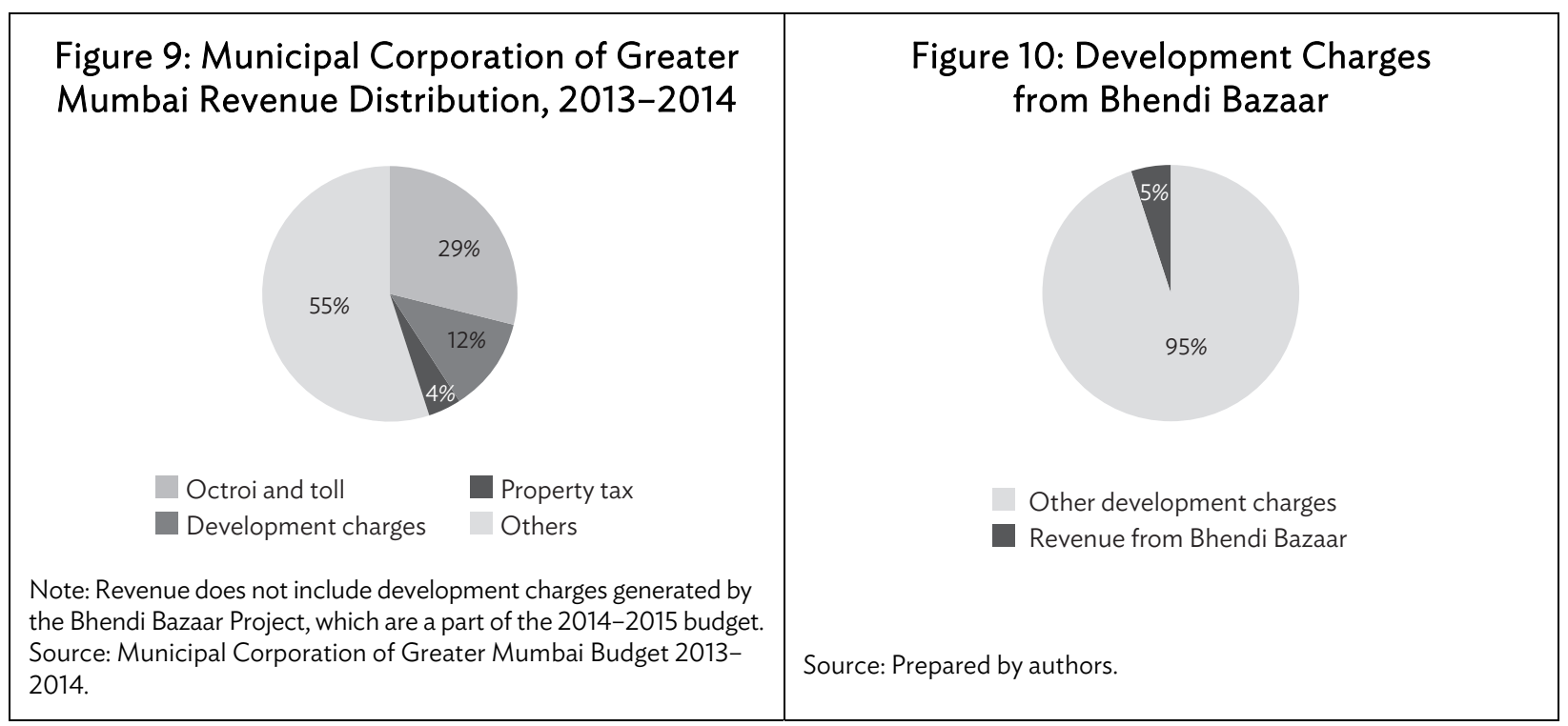

72. Socioeconomic impact. The immense success of Mumbai's redevelopment policy can be attributed to the limited availability of land that can be redeveloped. Although geographical constraints of the city are a major factor, intense speculation and artificial scarcity to drive up property prices have distorted the property market in Mumbai to a large extent. As a result, FAR incentives are in tremendous demand.

73. The government relinquished its role of providing affordable housing for slum dwellers, and middle- and low-income households by using FAR incentive-based urban redevelopment as a fiscal tool to attract private developers. Since developers have to rehouse existing occupants free of cost, they try to extract maximum possible incentives, and at times misuse the policy, as was evident prior to the provision of fungible FAR.

74. Providing free housing is not economically sustainable in the long term. Even though it appears that the developers have to incur an expense for rehabilitating properties for existing occupants, the actual costs are passed on to new homebuyers. As a result, the market value of new apartments has risen tremendously, making it difficult for even the upper-middle class residents to purchase real estate in the city. Recent years have seen numerous luxury residential apartments lying vacant in Mumbai.

75. Spatial and physical impact. Although the policy lays out guidelines in the form of setbacks and open spaces, these have been ineffective in regulating the overall built form. Numerous redeveloped buildings have public parking on the first four levels to obtain more FAR incentives. This has degraded the street character and pedestrian experience. Plots in the inner-city areas are small, with very narrow access roads. The provisions of the policy have resulted in high-rise buildings crowding close to each other on narrow streets. Access to natural light, adequate ventilation, and dispersal of traffic have become major issues. A recent judgment by the Supreme Court led to the amendment of the policy, with greater setback requirements, but challenges persist. Additionally, redevelopment projects located in historic precincts, have completely disregarded the urban form and scale in their surroundings, obliterating the distinct urban fabric. 


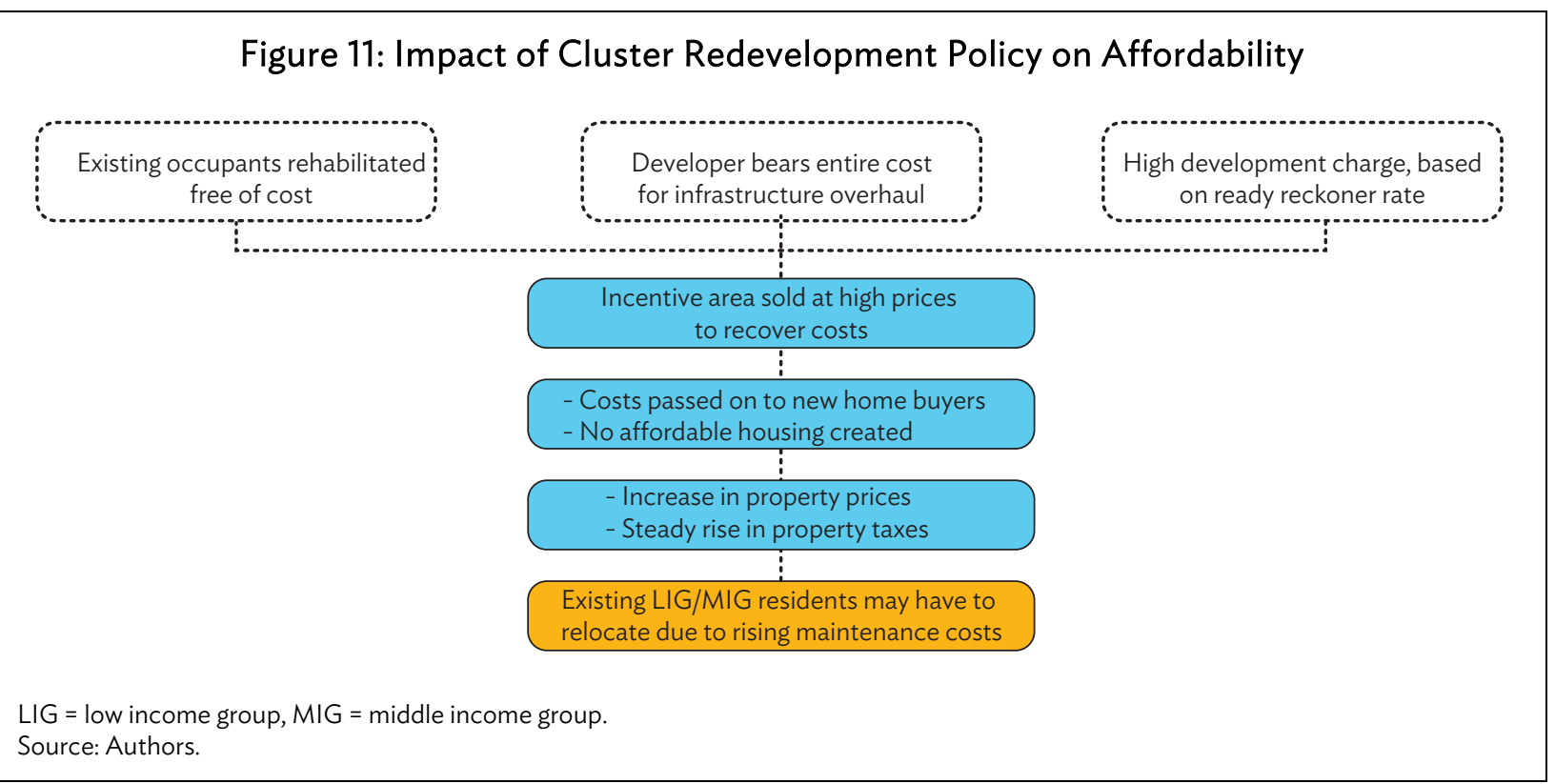

76. When higher FAR and incentives were initially proposed through the policy, a comprehensive analysis of the impact of increased built-up areas on urban services such as water supply, sewerage disposal, solid waste management, and traffic was not conducted. As a result, augmentation of urban services has not kept pace with the redevelopment projects in the city. Services such as water supply, sewerage, and roads are stretched thin due to the increase in demand postredevelopment.

Table 11: Analysis of Cluster Redevelopment in Mumbai

\begin{tabular}{l|l|l}
\hline \multicolumn{3}{c}{ GOOD PRACTICES } \\
\hline Physical & \multicolumn{1}{c}{ Administrative } & \multicolumn{1}{c}{ Fiscal } \\
\hline $\begin{array}{l}\text { Reconfiguration of narrow plots } \\
\text { into larger blocks. }\end{array}$ & $\begin{array}{l}\text { Assignment of rehabilitated } \\
\text { units regulated by MHADA. }\end{array}$ & $\begin{array}{l}\text { Incentives in the form of high FAR for } \\
\text { housing existing occupants. }\end{array}$ \\
\hline $\begin{array}{l}\text { Well-developed street network, } \\
\text { overhaul of urban services. }\end{array}$ & $\begin{array}{l}\text { Environmental impact } \\
\text { assessment mandatory. }\end{array}$ & $\begin{array}{l}\text { Development charges major contributor } \\
\text { to public revenue. }\end{array}$ \\
\hline \multicolumn{3}{c}{ SHORTCOMINGS } \\
\hline Physical & \multicolumn{1}{c}{ Administrative } & \multicolumn{1}{c}{ Fiscal } \\
\hline Clusters not demarcated in CDP. & $\begin{array}{l}\text { Difficult to acquire consent of } \\
\text { landowners and tenants. }\end{array}$ & $\begin{array}{l}\text { Very high upfront capital investment } \\
\text { required. }\end{array}$ \\
\hline $\begin{array}{l}\text { Model requires very high } \\
\text { incentives, may cause congestion. }\end{array}$ & $\begin{array}{l}\text { Slow approvals process, too } \\
\text { many agencies involved. }\end{array}$ & Returns only after some years. \\
\hline $\begin{array}{l}\text { Density increase not linked to } \\
\text { upgrading city level infrastructure } \\
\text { networks. }\end{array}$ & $\begin{array}{l}\text { Delays caused by corrupt } \\
\text { practices. }\end{array}$ & $\begin{array}{l}\text { Development not affordable to new } \\
\text { homebuyers, will price out LIG/MIG } \\
\text { households in the long run. }\end{array}$ \\
\hline
\end{tabular}

$\mathrm{CDP}=$ City Development Plan, FAR = floor area ratio, $\mathrm{LIG}=$ low income group, MHADA = Maharashtra Housing and Area Development Authority, MIG = middle income group.

Source: Authors. 
77. The procedure for project approvals is extremely lengthy and involves MHADA and more than 13 MCGM departments. Corrupt practices often lead to delays in getting approvals. A single-window system of submitting approvals and checking their status online has been initiated by MCGM in recent years. Although still in its early stages, it seems to be a step in the right direction. Evolving and developing this system through user consultations will be imperative in making the building proposal approval process transparent and efficient.

\section{Box 4: Vanderbilt Corridor Rezoning: Linking New Commercial Development to Transit and Public Realm Improvements}

Vanderbilt Avenue is the main gateway to the Grand Central Terminal in New York City and was a taxi access point. After the taxi access was moved for security reasons, the area became relatively bleak. The portion of Vanderbilt Avenue adjacent to the Grand Central Terminal does not offer a welcoming environment to commuters, residents, and visitors alike (CPC 2015). The special permit issued in 1992 allows additional density in the area through provision of infrastructure improvements. However, they were insufficient to attract the investment required to address existing infrastructure challenges. Hence, the Department of City Planning proposed rezoning five blocks of the Vanderbilt Corridor that are bounded by Madison and Vanderbilt avenues to the west of Grand Central Terminal. The proposal was approved in May 2015.

In accordance with the proposal, the zoning terms of the Grand Central Subdistrict pertaining to the five blocks in the Vanderbilt Corridor was amended. The amendment established a special permit for a Grand Central public realm improvement bonus, changed the Grand Central subdistrict landmark transfer special permit, and changed the uses permitted in the corridor (CPC 2015). The One Vanderbilt proposal was the first to receive the new Special Permit for Grand Central Public Realm Improvement Bonus. SL Green, a leading real estate developer in New York City, proposed a new 68-story office tower on the block immediately west of Grand Central, between East 42nd and East 43rd Streets, that will utilize development rights from the landmark Bowery Savings Bank building. An overall floor area ratio (FAR) of 30 has been proposed, along with a range of on- and off-site public realm improvements that qualify for a bonus of 12.37 FAR. The design of the tower integrates features that complement the architecture of Grand Central Terminal, and the massing steps back for the first three floors, enabling clear views of the Grand Central cornice. The proposed uses consist of retail on the ground floor with office space in the rest of the tower (CPC 2015).

SL Green proposed numerous on- and off-site amenities to improve the pedestrian circulation network around Grand Central that would generate a bonus of 12.37 FAR. The costs incurred for construction of these amenities is approximately $\$ 220$ million.

The on-site improvements are as follows:

(i) There is a new subway entrance on East 42nd Street with escalator, elevator, and stairway access to the shuttle subway station;

(ii) There is a 370-square meter Transit Hall with entrances on East 43rd Street that gives stairway and elevator access to the new intermodal connector of Grand Central. This area will have numerous public amenities, such as waiting spaces, and schedule indicators;

(iii) There are new elevator and escalator connections from East Side Access to the street or subway lines through the development site;

(iv) There is a new intermodal connector. 
Box 4 continued

The off-site improvements are

(i) Design of the Vanderbilt Avenue Public Place as a pedestrian plaza with amenities such as public seating and landscaping;

(ii) New stair in the cellar of the Pershing Square Building to connect Grand Central Subway mezzanine to platforms 4, 5, and 6;

(iii) A new subway entrance with two street level subway stairs in the sidewalk at the southeast corner of East 42nd Street and Lexington Avenue;

(iv) Creation of 8,475 square feet of new and expanded Grand Central mezzanine areas in the cellar of Grand Hyatt Hotel; and

(v) Replacement and widening of existing street-level subway entrance at the northwest corner of East 42nd Street and Lexington Avenue.

Source: City Planning Commission. 2015. Application for Rezoning of Vanderbilt Avenue. Department of City Planning, New York City.

\section{B. Local Area Planning in Ahmedabad}

78. The city of Ahmedabad has been at the forefront of progressive and innovative urban development in India. The recently formulated local-area proposal for transforming Ahmedabad's city center is one of the few policies in India that integrate linking FAR premiums with augmentation of local infrastructure, while at the same time stressing on achieving a cohesive urban form and the importance of urban design strategies.

79. In response to the rapid growth of urban areas and the need to manage land use and provide infrastructure and urban services, the State of Gujarat passed the Gujarat Town Planning and Urban Development Act in 1976 (India Infrastructure Report 2009). Under the provisions of this act, urban areas were defined and boundaries urban and/or area development authority boundaries were established. Ahmedabad Urban Development Authority (AUDA) is an agency that functions within the boundaries of urban Ahmedabad, preparing development plans for the urban area.

80. The city of Ahmedabad is a major urban center in Gujarat and the seventh largest city in India (Table 12). The city experienced rapid spatial expansion and tremendous population growth in the last decade. The Ahmedabad Municipal Corporation (AMC) and AUDA have been tackling rapid urbanization in the metropolitan area by adopting innovative mechanisms such as town planning schemes, the levy of development charges, and the use of FAR incentives for slum redevelopment. Ahmedabad also has a policy for redevelopment of old buildings (constructed in 1950s-1970s) using 2.7 FAR.

81. Political and Economic Environment. Ahmedabad City can be broadly classified into two areas - the old walled city and the new city. The Sabarmati River separates the two. The city has three commercial districts. The Lal Darwaja area in the Old City is home to wholesale markets and is a major trade center. The main central business district (CBD) of the city is located in the new city, along Ashram Road, which mostly houses government offices and institutions. The Sarkhej-Gandhinagar (SG) Highway is an upcoming road that was earlier a national highway. It is currently the most in-demand area in the city, with numerous corporate offices and affluent housing that reduced the distance between their homes and the workplace for many people. 
Table 12: Urban Profile of Ahmedabad Urban Area

\begin{tabular}{ll}
\hline Area & $464.16 \mathrm{~km}^{2}$ \\
\hline Population (2011) & 6.4 million \\
\hline Population Density (2011) & 12,000 persons $/ \mathrm{km}^{2}$ \\
\hline Growth Rate (2008) & $10.1 \%$ (unverified) \\
\hline $\mathrm{km}^{2}=$ square kilometer. \\
Source: Ahmedabad Urban Development Authority.
\end{tabular}

82. Legal and Policy Framework. The 2012 Development Plan for Ahmedabad zoned the city into varying FAR zones on the basis of location and land use. The primary classifications are: residential, transit-oriented zones (TOZs); and the CBD. Each zone has different permissible FAR with free FAR up to a certain value, above which a premium has to be paid to AMC. The premium amount is $40 \%$ of the Standard Land Rate (SLR) or Jantri Rate, determined by the Government of Gujarat (Table 13).

Table 13: Permissible Floor Area Ratio in Ahmedabad

\begin{tabular}{lc}
\hline Zone & Permissible FAR \\
\hline R1 (Residential) & 2.7 \\
R2 (Residential) & 1.8 \\
TOZ (Mixed Use) & 4.0 \\
Ashram Road CDB (Commercial) & 5.4 \\
\hline \multicolumn{2}{c}{ CDB = central business district, FAR = floor area ratio, TOZ = transit } \\
oriented zone. \\
Source: Ahmedabad Urban Development Authority.
\end{tabular}

83. The higher FAR in the $\mathrm{R} 1$ residential zone facilitates redevelopment of old buildings and obsolete structures. An FAR of 4 has been proposed along BRTS and Metro corridors, and along major roads to exploit the potential created by transit access, promoting mixed-use development.

84. Rejuvenating Ahmedabad's City Centre, Ashram Road. The Ashram Road Central Business District is the city center of modern Ahmedabad. However, low FAR restricted the scope of property developments. The old buildings are small and rundown, whereas the newly constructed buildings are small and lackluster (Patel 2015). Currently, the area comprises 31 blocks, and has a very deficient street network. Existing streets are narrow, covering just $22 \%$ of the city center land area. The pedestrian experience is unpleasant due to inadequate infrastructure.

85. To promote development of the city center, AMC and AUDA have been strengthening the public transit network of Ahmedabad with the introduction of a BRTS and Metro. The 2012 Development Plan increased the FAR permissible in this area to 5.4. Recognizing the need to augment the capacity of urban infrastructure in the center and absorb excess development potential and prevent congestion, AMC and AUDA agencies have drawn up a Local Area Development Proposal for the city center. The primary objective of this proposal is to integrate transportation and land use planning to reduce travel times and transform the city center into a high density, mixed-use area.

86. The proposal reconfigures the plots during redevelopment by imposing setbacks to appropriate space for new streets, and for widening existing streets. This made the new block sizes walkable and 
pedestrian friendly (Figure 12). A large setback of $9 \mathrm{~m}$ has been proposed along Ashram Road, which is the spine of the area. Setbacks of $6 \mathrm{~m}$ have been proposed for all other streets. This will expand the public realm by creating new streets and increasing the street coverage to $44 \%$. The connectivity to the riverfront will also improve. The building bylaws for the city center have been simplified for ease of interpretation. The proposal defines a development envelope by permitting buildings on the entire plot area minus setbacks up to a height of $86 \mathrm{~m}$ (as per Airport Authority Regulations). The possible development envelope is greater than the permissible building size as an FAR of only 1.8 is permitted as of right. Additional FAR up to 5.4 is available for construction on payment of a premium. Development potential of one site can be transferred to another within the CBD using the TDR mechanism. Urban design regulations have been drawn up for Ashram Road. Development has to be built to line and a continuous arcade along the length of the street is mandatory. A detailed survey of plots within the CDB has been carried out to establish existing and new boundaries. Permissible building footprints and new road layouts have been carefully compiled and integrated into the new building regulations. Open spaces within blocks have also been proposed (Table 14).

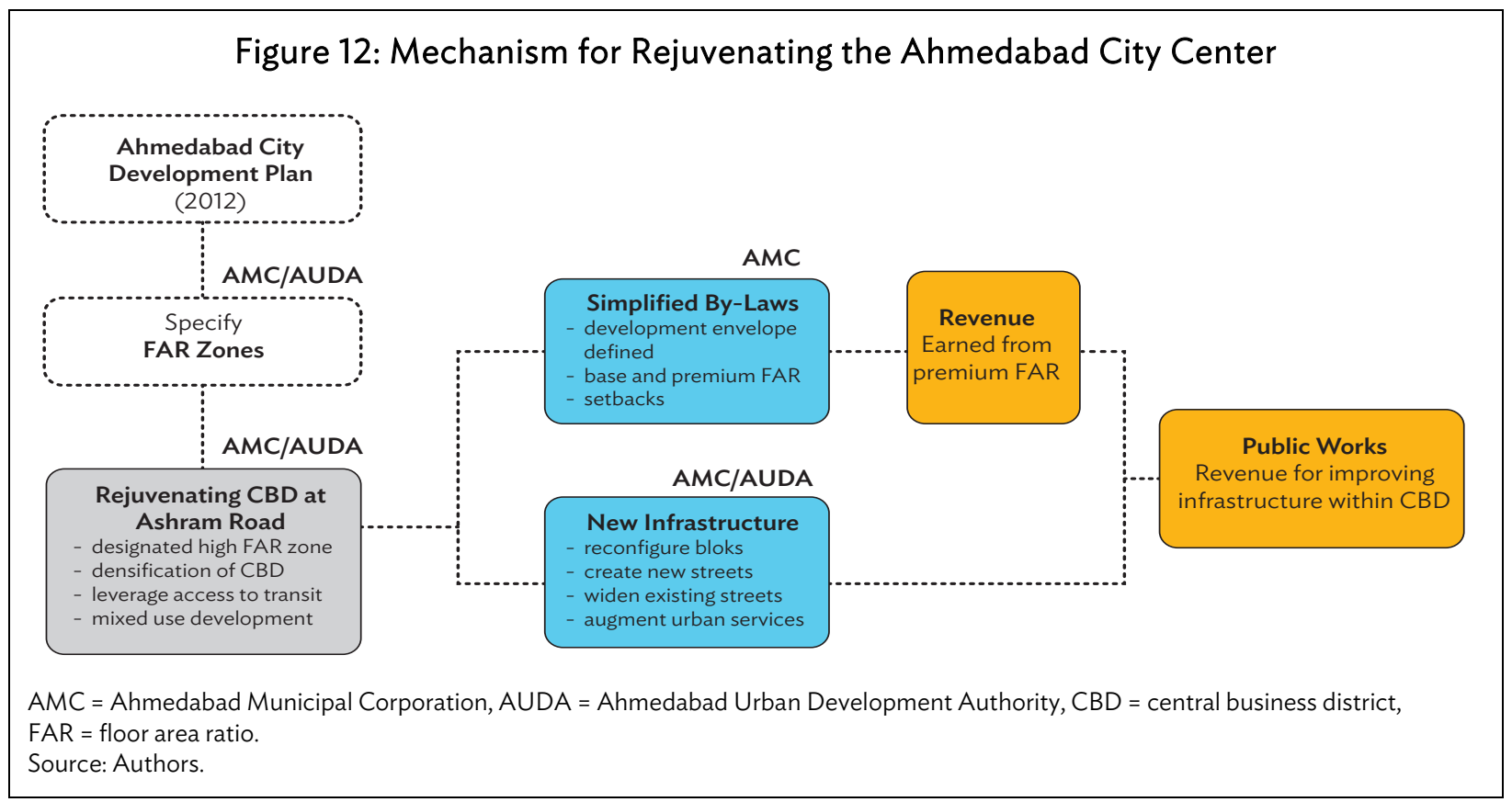

Table 14: Existing and Proposed Scenario for the Ahmedabad City Center

\begin{tabular}{lcc}
\hline Parameter & Existing & Future \\
\hline FAR (Plot) & 1.8 & 5.4 \\
FAR (Gross) & 1.0 & 5.0 \\
Total Built Up Area & $1,275,000 \mathrm{~m}^{2}$ & $5,400,000 \mathrm{~m}^{2}$ \\
Population & 85,000 & $2,00,000$ \\
Street Coverage (Public Domain) & $22 \%$ & $40 \%$ \\
Number of Blocks & 31 & 76 \\
Average block perimeter & $743 \mathrm{~m}$ & $416 \mathrm{~m}$ \\
Green Cover in Public Domain & $6 \%$ & $30 \%$ \\
\hline
\end{tabular}

$F A R=$ floor area ratio, $m=$ meter,$m^{2}=$ square meter .

Source: B. Patel. 2015. HCP Presentation. Launch of India Smart Cities Mission. 25 June. 
87. A vertical and horizontal mix of uses is proposed with shared underground parking spaces. According to the proposal, smart infrastructure will be funded by the revenue obtained from selling FAR. The proposal has been formulated through a participatory process that saw citizens of Ahmedabad providing input and expressing concern about the project. It also integrates provision of space for the informal sector.

88. Impact on Municipal Revenue. AMC and AUDA projected revenue scenarios for different development levels. Sale of $50 \%$ of available premium FAR is expected to generate revenue of $\$ 3.5$ million (Table 15).

Table 15: Expected Revenue from Premium Floor Area Ratio

\begin{tabular}{|c|c|c|c|}
\hline Development Level & $\begin{array}{c}\text { Built Up Area } \\
\text { Generated by } \\
\text { FAR Incentive } \\
\left(\mathrm{m}^{2}\right)\end{array}$ & $\begin{array}{c}\text { Jantri Rate } \\
\left(\$ \text { per } \mathrm{m}^{2}\right)\end{array}$ & $\begin{array}{c}\text { Anticipated } \\
\text { Revenue } \\
\text { (\$ million) }\end{array}$ \\
\hline $30 \%$ Redevelopment & $2,95,094 \mathrm{~m}^{2}$ & 500 & 2.0 \\
\hline $50 \%$ Redevelopment & $4,91,824 \mathrm{~m}^{2}$ & 500 & 3.5 \\
\hline
\end{tabular}

$\mathrm{FAR}=$ floor area ratio, $\mathrm{m}^{2}=$ square meter.

Source: Ahmedabad Urban Development Authority (2015).

89. Summary of case findings. Ahmedabad's proposal to redevelop its CBD is comprehensive but holistic. Redevelopment of individual properties may take a long time, depending on conditions prevailing in the city's real estate market. However, the proposal has potential to evolve into a more robust approach. Key findings are as follows (Table 16):

(i) A comprehensive assessment of the real estate market in Ahmedabad has never been undertaken. Currently, the city has some of the highest vacancy rates in India, with an oversupply of luxury apartments and a large number of unsold residential flats. Moreover, since the SG Highway is the most popular location for real estate development, the demand for extra FAR in the Ashram Road CBD may not be as estimated by AMC and AUDA.

(ii) FAR incentives have previously been granted in Ahmedabad along the BRTS corridor. These received a very mixed response, since actual requirements were not assessed in greater depth. Ahmedabad also has a provision for TDR for heritage properties, which has not been very successfully applied.

(iii) Redevelopment is an extremely lengthy and complex process. It is speculative to project the demand for extra FAR and assess the desire of landowners and developers to undertake such projects.

(iv) Neither AMC nor AUDA have quantified the infrastructure requirements generated by the extra FAR permitted by the development plan. However, a provision for charging an "impact fee" was established to fund infrastructure augmentation. The amount paid by developers to AMC and/or AUDA for acquiring building permissions is also relatively high ( $\$ 7.5$ per square meter). Thus, there is no precise mechanism to ensure that the revenue obtained from selling premium FAR in the CBD will be invested in specific urban amenities to serve the CBD. 
(v) In India, regularly raising taxes has political implications. However, Ahmedabad has an built-in provision that permits AMC to increase property taxes on a yearly basis. Despite this, property taxes generated from redeveloped properties will not be sufficient for capital expenditures on urban services.

Table 16: Analysis of Local Area Planning in Ahmedabad

\begin{tabular}{|c|c|c|}
\hline \multicolumn{3}{|c|}{ GOOD PRACTICES } \\
\hline Physical & Administrative & Fiscal \\
\hline $\begin{array}{l}\text { Densification promotes } \\
\text { compact urban form. }\end{array}$ & $\begin{array}{l}\text { Building bylaws simplified, base } \\
\text { and premium FAR defined. }\end{array}$ & $\begin{array}{l}\text { Revenue obtained from selling } \\
\text { premium FAR for improvements } \\
\text { within CBD. }\end{array}$ \\
\hline $\begin{array}{l}\text { Street network expansion } \\
\text { through setbacks. }\end{array}$ & $\begin{array}{l}\text { Redevelopment at discretion of } \\
\text { landowners. }\end{array}$ & \\
\hline \multicolumn{3}{|c|}{ SHORTCOMINGS } \\
\hline Physical & Administrative & Fiscal \\
\hline $\begin{array}{l}\text { Policy holistic, can't predict } \\
\text { time frame for full build out. }\end{array}$ & $\begin{array}{l}\text { No mechanism to link revenue } \\
\text { with infrastructure expenditure. }\end{array}$ & $\begin{array}{l}\text { Unsteady revenue flow from } \\
\text { premium FAR. }\end{array}$ \\
\hline $\begin{array}{l}\text { Urban services to support high } \\
\text { FAR not quantified in CBD. }\end{array}$ & & $\begin{array}{l}\text { Difficult to make financing plans } \\
\text { based on FAR revenue. }\end{array}$ \\
\hline
\end{tabular}

$\mathrm{CBD}=$ central business district, $\mathrm{FAR}=$ floor area ratio .

Source: Authors.

\section{Box 5: Use of Certificates of Potential Additional Construction Bonds to Rejuvenate Porto Maravilha in Rio De Janeiro, Brazil}

Porto Maravilha, Rio de Janeiro's port area, has seen reduced port activities over the past 2 decades, resulting in malfunctioning infrastructure, abandoned buildings, and overall deterioration of the urban fabric. The Rio de Janeiro municipal government used an urban operations mechanism to stimulate economic development in Porto Maravilha through physical revitalization of the neighborhood and its waterfront. Through interventions such as the development of a light-rail system, introducing bicycle lanes, and developing cultural spaces and parks, the city aims to revive the port area and create vibrant, mixed-use neighborhoods that integrate housing and cultural and commercial development with multimodal transportation.

Redevelopment commenced in 2009, with the initiation of the Urban Operation of the Port Region, and was estimated to cost approximately $\$ 3$ billion over 15 years. The costs of all public infrastructure improvement and future service expenses in the Porto Maravilha district are being covered through the sale of certificates of potential additional construction bonds (CEPACs). CEPACs were sold to Caixa Economica Federal, a single third-party vendor. Caixa placed them on the open market, where they were traded publicly, and were purchased by real-estate developers. 


\section{CONCLUSIONS AND RECOMMENDATIONS}

90. Promoting a highly dense and compact urban form using floor area ratio (FAR) incentives is a promising approach, with great potential to revitalize urban centers of cities in India. FAR incentives are essentially rooted in the concept of separating the ownership of land from the right to build on that land, which is stipulated by the urban local bodies (ULBs). Since cities control the development potential of land within their jurisdiction, they can leverage this right to promote a homogenous built form, influence sustainable spatial growth patterns, and achieve inclusive development through promotion of affordable housing as is done in New York City, and also upgrade urban neighborhoods by linking development potential and premiums to local infrastructure improvements, as is done in Brazil. Conversely, if used as a fiscal tool to generate municipal revenue, without a comprehensive spatial and infrastructure plan in place, it can lead to uncontrolled and ad hoc development that burdens urban services, as evidenced in Mumbai since the implementation of its redevelopment policy. Moreover, current FAR incentive practices in India also have significant socioeconomic implications. It is essential to address these by establishing safeguards before replicating this approach in other cities to ensure that redevelopment is inclusive and sustainable.

91. Since land and property markets vary from region to region, state governments should undertake statewide analyses of urban land markets and assess the development that each city within the state can absorb. New FAR values for redevelopment in each city can be determined based on such studies. Provision of incentive FARs for urban redevelopment will require that state governments amend their town planning acts and/or local development plans and regulations. Additionally, they will also need to make provisions for a mechanism to link revenue generated from selling premium FAR in one area to infrastructure investments in the same area (CEPAC auctions). Based on such market analysis, states can nominate cities capable of auctioning development rights. A state level agency can be established to handle the financial side of these auctions by collaborating with the states' public sector banks.

92. Land assembly is a key challenge in undertaking area-based redevelopment. Mechanisms for land readjustment and pooling, similar to those used in various cities in Gujarat and Maharashtra could be adapted for urban redevelopment. Ahmedabad has extensively used the Town Planning Scheme (TPS) mechanism for land pooling. Under this approach, the development plan of the city is prepared, and areas of up to 100-200 hectares, (usually on the urban fringe), which require infrastructure provision, are designated as TPS. Landownership details, maps, and land values of every plot of land in the designated area are carefully drawn up. A detailed master plan of the area with roads and social services is prepared, while the remaining land is reconstituted into new plots for the landowners. These plots are similar in size to the original plots, and located in the same place or as close as possible to the original location. A betterment charge is levied on the landowners for the increment in their land values due to the new infrastructure provided. The revenue from this charge is used to finance new infrastructure such as roads, water supply, sewerage, public parks, and so on. The entire process is carried out through extensive consultation with landowners and public participation (Ballaney 2008). Similar strategies can be used to resolve the deadlock between landowners and developers to expedite land assembly for redevelopment schemes.

93. Integrated spatial and infrastructure analysis requires considerable technical expertise and capacity. Numerous geographical information system-based programs and applications are available that enable planners to determine the impact of increased density and built-up areas on urban infrastructure. Scenarios for different levels of development can be predicted using these applications. Developing this application for cities in India can be undertaken as an extension of the National Urban 
Information System. The central government can engage the National Institute for Urban Affairs to create development prototypes for specific FAR values and land uses that could be used by cities.

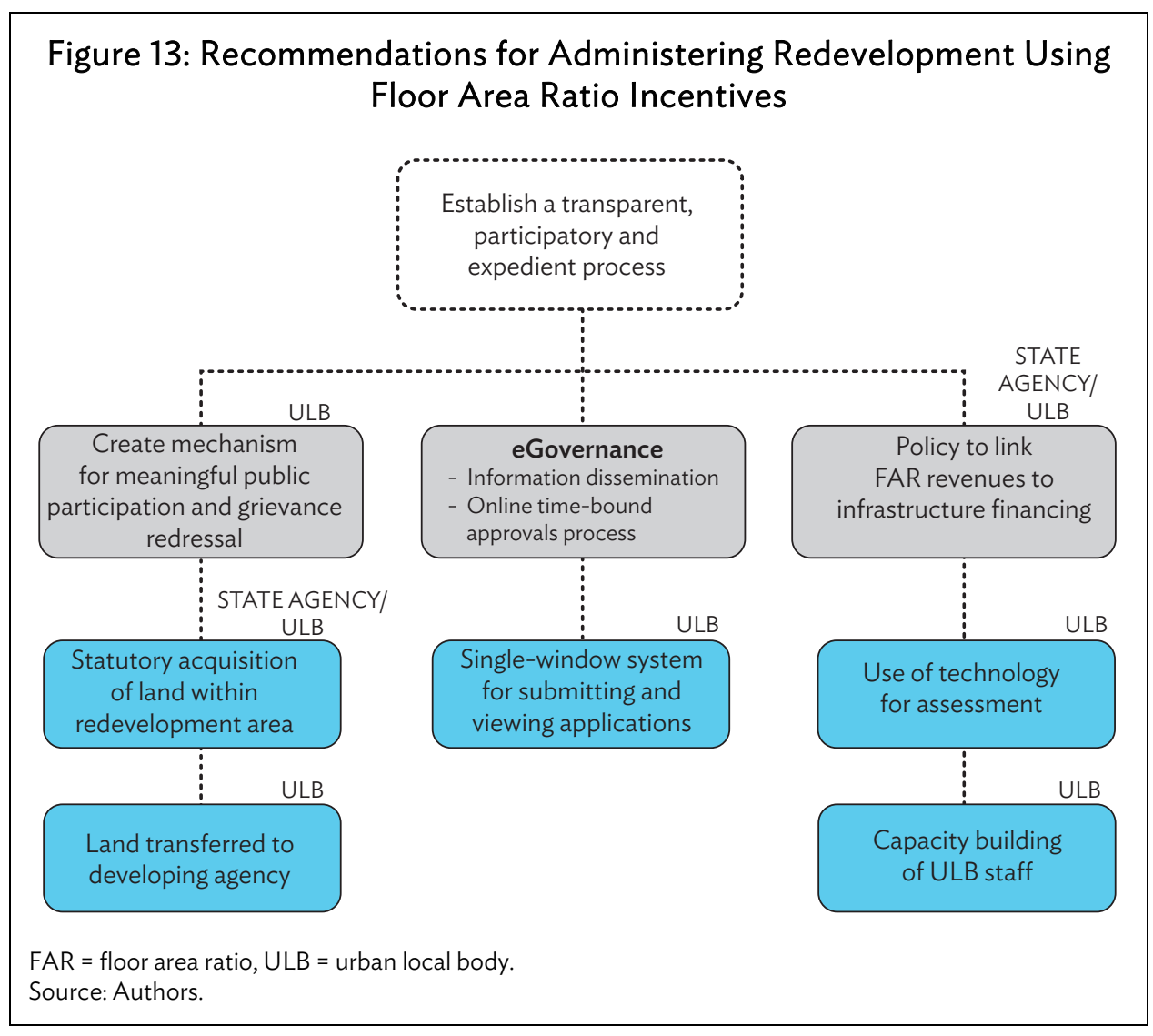

94. At the local level, ULBs should integrate redevelopment projects into the overall city development plan and not treat them as isolated clusters. This will ensure that the city can, in the future, replicate such projects in other neighborhoods. Additionally, increasing density in urban neighborhoods should also be accompanied by the provision of adequate amenities to service new developments. Developing public spaces such as parks, playgrounds, plazas, and trails is crucial. Three strategies will help achieve this (Figure 14):

(i) Preparation of a framework to assess infrastructure and financing requirements generated by increased FAR. This is similar to the mechanism used in Brazilian cities to determine the amount of CEPACs to be assigned to each land parcel in an urban operation. This will enable ULBs to assign higher FARs and upgrade infrastructure and urban amenities to match increased service needs, and more importantly ensure that revenue arising from FAR incentives from in a specific location is re-funneled into improving urban services in that area. As seen in the case of New York City, ULBs can use this assessment to enable private sector investment in public services by permitting land use departures (change in use or additional FAR) in exchange for provision of public amenities such as parks, plazas, streetscape improvements, etc. by developers. 
(ii) Defining redevelopment areas in city development plans with extensive stakeholder consultations. As seen in the case of New York City, this will ensure that the process of redevelopment is participatory, which is also a requirement of the Smart Cities Mission Guidelines.

(iii) Statutory urban design regulations and construction standards for new buildings. Cities in India have a rich built heritage and a vibrant street life. Such regulations will ensure that new development complements its urban setting. The ULBs also need to study natural systems, open-space distribution, and informal networks within these clusters and determine how redevelopment will affect them. This is key to ensuring that the new development is socially and environmentally sustainable. ULBs can also integrate climate change adaptation and mitigation strategies such as permeable surfaces, micro grids, energy efficiency guidelines, and so on to foster urban resilience.

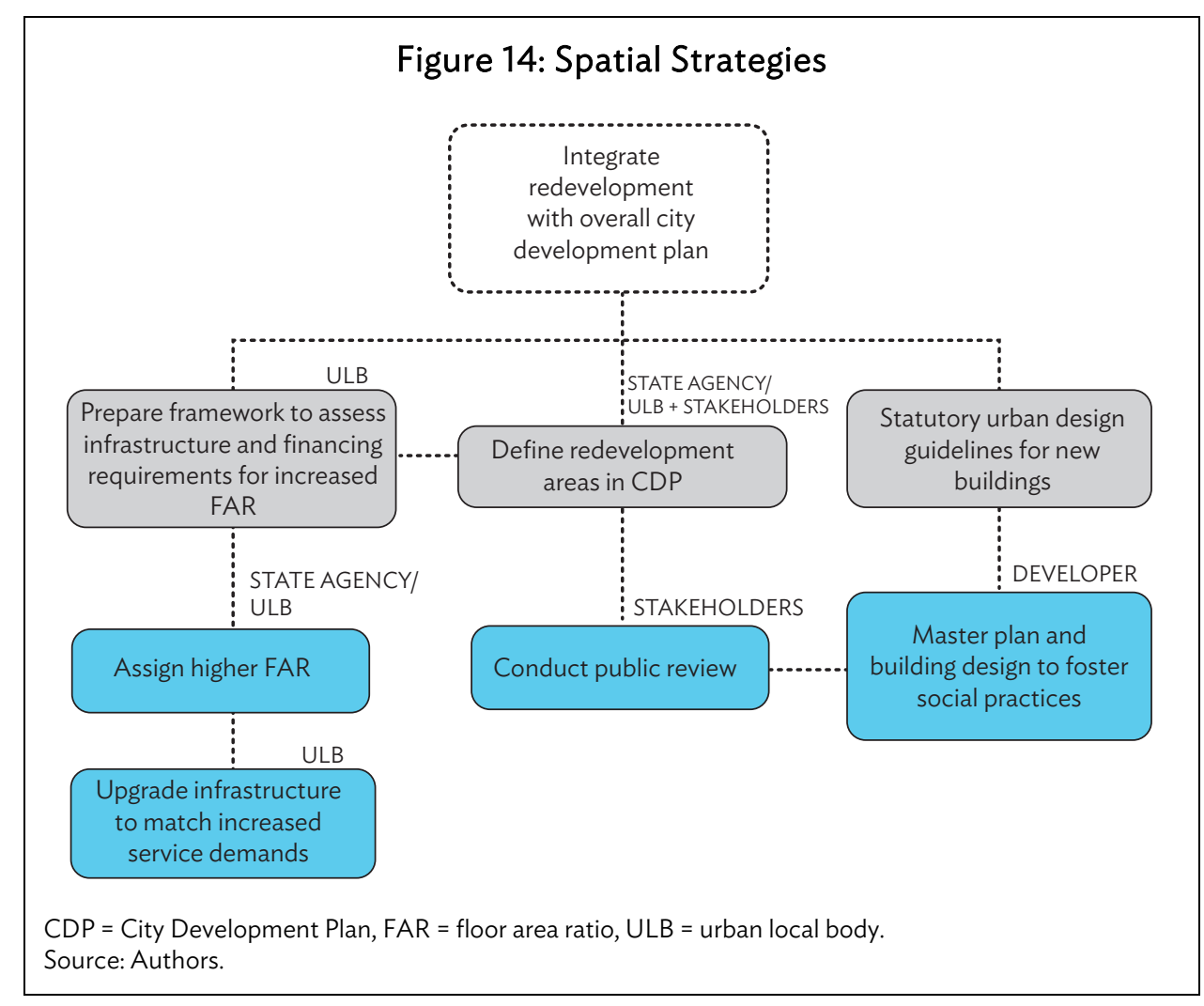

95. Fiscal strategies that promote inclusive redevelopment are essential. The following approaches would help facilitate this (Figure 15):

(i) Existing occupants partly pay for development costs to acquire ownership of new units. The state housing board may float financing programs, such as long-term, lowinterest loans to support existing tenants.

(ii) Including an affordable housing component. Since existing tenants have to pay a portion of development costs, incentives required would be reduced. FAR bonuses can instead be used to cross-subsidize construction of affordable units. 
(iii) Public assistance for infrastructure overhaul. The cost for upgrading all service lines within a cluster of the area specified in Mumbai's policy can amount to $\$ 45$ million. Development costs can be reduced if public agencies fund a part of this expenditure. This will ensure that saleable units are sold at relatively lower costs, making them more affordable to a larger section of new homebuyers. It will also contain the rise in property prices and maintenance costs, making the new development significantly more affordable.

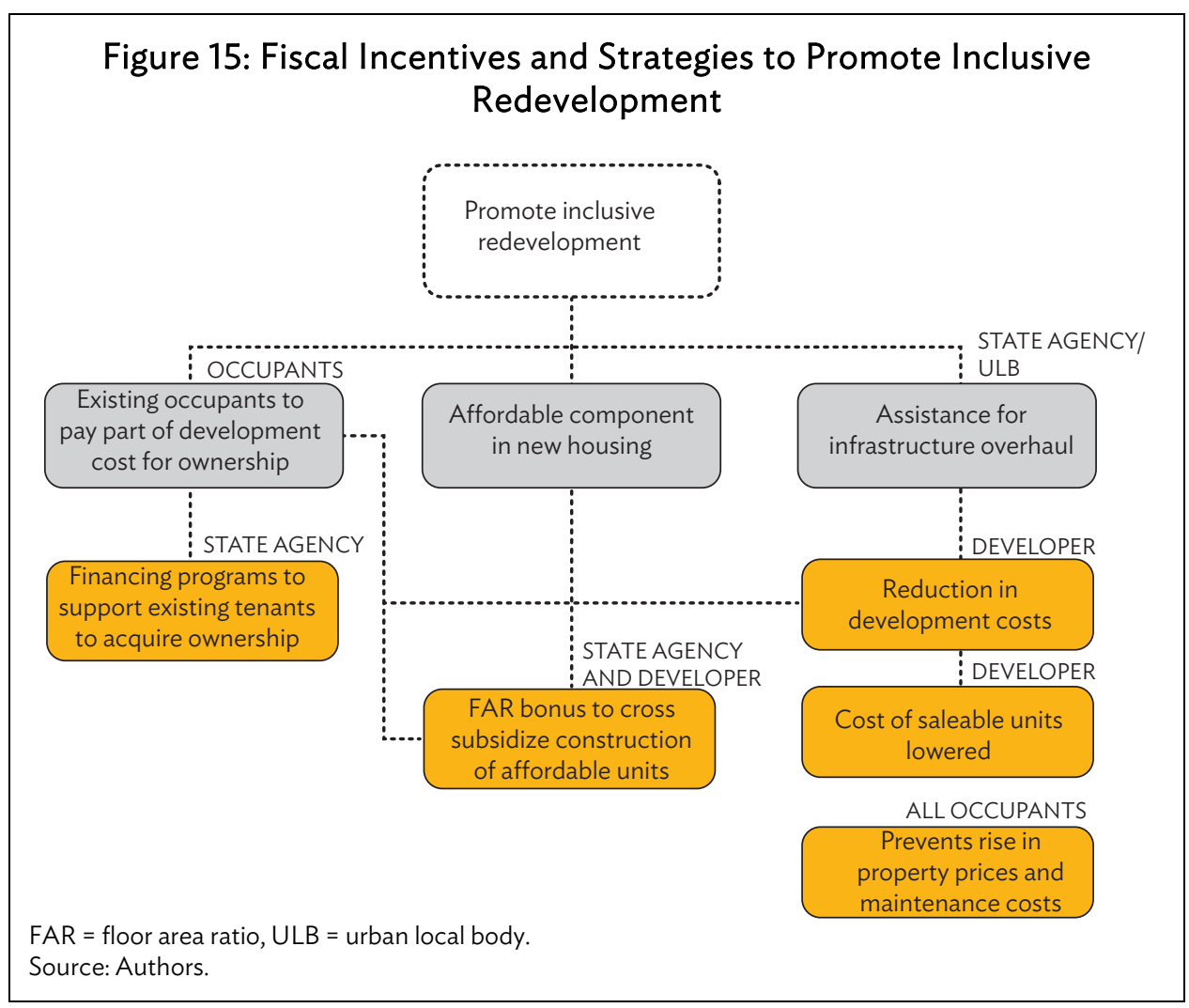




\section{REFERENCES}

Ahluwalia, I. J. 2011. Planning for Urban Development in India. ICRIER.

Aditya, A. and V. Pankti. 2011. Rent Control in India-Obstacles for Urban Reform. NUJS Law Review 81.

Ahmedabad Urban Development Authority. www.auda.org.in.

Atal Mission for Rejuvenation and Urban Transformation. www.amrut.gov.in.

Bakore, M. 2007. Urban Land Ceiling Act: Appeal to Repeal. CCS Services on NURM Reforms, Centre for Civil Society.

Ballaney, S. 2008. The Town Planning Mechanism in Gujarat, India. Washington, DC: The World Bank.

Bertaud, A. 2011. Mumbai's Ill-Conceived Malthusian Approach to Development. http://alainbertaud.com/wp-content/uploads/2013/06/AB-Mumbai-FSI-Conundrun-

Revised_June-2013_kk-ab1.pdf.

Alain Bertaud. www.alainbertaud.com.

Bertaud, A., and J. K. Brueckner. 2005. Analyzing Building-Height Restrictions: Predicted Impacts and Welfare Costs. Regional Science and Urban Economics. 35 (2). pp. 109-125.

Biderman, C. Sandroni, Paulo and Smolka, Martim O.. 2006. Large-Scale Urban Interventions: The Case of Faria Lima in São Paulo. Land Lines 18 (2). pp. 8-13.

Blaesser, B. W., and T. P. Cody, eds. 2008. Redevelopment: Planning, Law, and Project Implementation. Chicago: State and Local Government Law, American Bar Association. pp. 3-10.

City Planning Commission. 2015. Application for Rezoning of Vanderbilt Avenue. Department of City Planning, New York City.

Dev, S. 2006. Rent Control Laws in India: A Critical Analysis. CCS Working Paper No. 158. Centre for Civil Society.

Downs, A., and Brookings Institution. 1981. Neighborhoods and Urban Development. Washington, DC. Brookings Institution.

Escher Group. Five, ICT Essentials for Smart Cities. Whitepaper for Business.

Firmino, R. 2005. Planning the Unplannable: How Local Authorities Integrate Urban and ICT Policy Making. Journal of Urban Technology, 12 (2). pp. 49-69.

Gotham, K. F. 2001. Critical perspectives on Urban Redevelopment. Emerald Group Publishing.

Government of India, Ministry of Urban Development, High Powered Expert Committee. 2011. Report on Indian Urban Infrastructure and Services. 
2015. Smart Cities Mission. http://smartcities.gov.in.

Granath, M., and K. Axelsson. 2014. Stakeholders' Views on ICT and Sustainable Development in an Urban Development Project. ECIS 2014 Proceedings.

Huang, W. 2012. ICT-Oriented Urban Planning Strategies. Journal of Urban Technology. pp. 1-21.

Infrastructure Development Finance Company. 2009. Land-A Critical Resource for Infrastructure. India Infrastructure Report. Oxford University Press, New Delhi.

Horita, M. 2009. Innovations in Collaborative Urban Regeneration. CSUR-UT Series 6. Tokyo, New York. Springer Verlag.

Karteek, G. 2015. Is FSI Dependent on Land Availability and Densities? A Comparative Review of FSI in Indian Cities. European Journal of Sustainable Development, 4 (2). pp. 27-34.

Khan, Z., D. Ludlow, W. Loibl, and K. Soomro 2014. ICT-Enabled Participatory Urban Planning and Policy Development. Transforming Government: People, Process and Policy. 8 (2). p. 205.

Kumar, N. V. Kumar, K. M. Ali, and S. Krishnan. Improving Municipal Efficiency Using GIS. Information Systems Directorate, Ministry of Municipalities Affairs and Urban Planning: Kingdom of Bahrain.

Lassar, T. and Urban Land Institute. Carrots and Sticks: New Zoning Downtown. Washington, DC: Urban Land Institute.

Law, C. K., J. C. W. Chan, E. W.T. Chui, Y. C. Wong, K. M. Lee, and F. L. Y. Chau. 2009. Urban Renewal Policies in Asian Cities for the Urban Renewal Strategy Review Study Report. University of Hong Kong.

Lincoln Institute of Land Policy. www.lincolninst.edu.

Maharashtra Housing and Area Development Authority. https://mhada.maharashtra.gov.in/.

Mehrotra, R., and A. N. Lambah. 2004. Conservation after Legislation: Issues for Mumbai. Mumbai: Urban Design Research Institute.

Mehta, C. Views on Cluster Redevelopment.

Ministry of Urban Development. www.moud.gov.in.

Mohanty, P. K. 2003. Financing Urban Infrastructure: Some Innovative Practices of Local Resource Mobilization. CGG Working Paper.

Mukhija, V. 2003. Squatters as Developers?: Slum Redevelopment in Mumbai. Aldershot, Hampshire, England; Burlington, VT.

Municipal Corporation of Greater Mumbai. www.mcgm.gov.in. 
Munshi, N., and D. Dave. Integrated Multi Modal Transit Hub at Central Business District, Ahmedabad. AUDA.

Nallathiga, R. 2003. The Impacts of Density Regulation: A Case Study of Mumbai. 47th World Cities Congress, Vienna.

2005. Regulatory Impacts on Land and Housing Markets in Mumbai. Nagarlok 2005.

2012. Utilizing Transferable Developments in the City Development: An Experience of Mumbai. SSRN Working Paper Series. April.

Patel, B. 2015. Transforming Ahmedabad's City Center. HCP Presentation at Launch of the Smart City Mission, 2015.

Phatak, V. K. 2013. Land-Based Fiscal Tools and Practices for Generating Additional Financial Resources. CBUD: MoUD and World Bank.

Porto Maravilha. www.portomaravilha.com.br.

Reform Primer. Repeal of Urban Land Ceiling and Regulation Act.

Sandroni, P. 2010. A New Financial Instrument of Value Capture in São Paulo: Certificates of Additional Construction Potential. G. K. Ingram and Y.-H. Hong, eds. Municipal Revenues and Land Policies. Lincoln Institute of Land Policy.

2011. Urban Value Capture in São Paulo Using a Two-Part Approach: Created Land (Solo Criado) and Sale of Building Rights (Outorga Onerosa do Direito de Construir). An Analysis of the Impact of the Basic Coefficient of Land Use as a Tool of the 2002 Master Plan. Cambridge, Mass.: Lincoln Institute of Land Policy.

Sandroni, Paulo. www.sandroni.com.br.

Shenvi, A. 2014. Outsourced Housing: Impact of Rent Control on Mumbai's Housing Scenario. Harvard University Graduate School of Design. Unpublished paper.

Singh, A. 2015. Floor Area Ratio Controls in Hyderabad: A Case of Facilitating Densification through DeRegulation?

Smart Cities Mission. www.smartcities.gov.in.

Sridhar, K. 2010. Impact of Land Use Regulations: Evidence from India's Cities. Urban Studies, 47 (7). pp. 1541-1569.

Tewari, M., Godfrey. N., et al. Better Cities, Better Growth: India's Urban Opportunity. New Climate Economy, World Resources Institute, and Indian Council for Research on International Economic Relations. London; Washington, DC; and New Delhi. 
World Bank. 2013. Urbanization beyond Municipal Boundaries: Nurturing Metropolitan Economies and Connecting Peri-Urban Areas in India.

United Nations Department of Economic and Social Affairs. https://www.un.org/development/ desa/en/.

UN-Habitat. 2011. A New Strategy of Sustainable Neighborhood Planning: Five Principles.

- 2014. Urban Patterns for a Green Economy: Leveraging Density.

Weinstein, L. 2014. The Durable Slum: Dharavi and the Right to Stay Put in Globalizing Mumbai. Minneapolis: University of Minnesota Press. 


\section{Enabling Smart Urban Redevelopment in India through Floor Area Ratio Incentives}

Rapid urbanization puts tremendous stress on Indian cities. In the last 2 decades, India's urban population has increased exponentially, with 420 million Indians-33\% of the population-living in cities in 2015. Experts estimate that urbanization will peak in 2050, with more than half of India's population living in cities. In 2015, the Smart Cities Mission was launched to transform and improve livability in urban areas through various redevelopment strategies including land-value capture mechanisms. This paper assesses one such measure, Floor Area Ratio incentives, and draws on lessons learned from international experiences to understand the potential for stimulating urban redevelopment and improving quality of life in Indian cities.

\section{About the Asian Development Bank}

ADB's vision is an Asia and Pacific region free of poverty. Its mission is to help its developing member countries reduce poverty and improve the quality of life of their people. Despite the region's many successes, it remains home to a large share of the world's poor. ADB is committed to reducing poverty through inclusive economic growth, environmentally sustainable growth, and regional integration.

Based in Manila, ADB is owned by 67 members, including 48 from the region. Its main instruments for helping its developing member countries are policy dialogue, loans, equity investments, guarantees, grants, and technical assistance. 